\title{
Immature myeloid progenitors promote disease progression in a mouse model of Barrett's-like metaplasia
}

\author{
Jianping Kong ${ }^{1}$, Hong Sai ${ }^{1}$, Mary Ann S. Crissey ${ }^{1}$, Nirag Jhala ${ }^{2}$, Gary W. Falk ${ }^{1}$, \\ Gregory G. Ginsberg ${ }^{1}$, Julian A. Abrams ${ }^{3}$, Hiroshi Nakagawa ${ }^{1}$, Kenneth Wang ${ }^{4}$, Anil \\ K. Rustgi ${ }^{1}$, Timothy C. Wang ${ }^{3}$, John P. Lynch ${ }^{1}$ \\ ${ }^{1}$ Division of Gastroenterology, Department of Medicine, University of Pennsylvania, Philadelphia, PA, USA \\ ${ }^{2}$ Department of Pathology, Temple University, Philadelphia, PA, USA \\ ${ }^{3}$ Division of Gastroenterology, Columbia University, New York, NY, USA \\ ${ }^{4}$ Division of Gastroenterology, Mayo Clinic, Rochester, MN, USA \\ Correspondence to: \\ John P. Lynch, e-mail: lynchj@mail.med.upenn.edu \\ Keywords: Barrett's esophagus, myeloid-derived suppressor cells (MDSC), IL-17, S100A9, IL-1 $\beta$ \\ Received: August 14, $2015 \quad$ Accepted: October 02, $2015 \quad$ Published: October 12, 2015
}

\section{ABSTRACT}

Cdx2, an intestine specific transcription factor, is expressed in Barrett's esophagus (BE). We sought to determine if esophageal Cdx2 expression would accelerate the onset of metaplasia in the $L 2-I L-1 \beta$ transgenic mouse model for Barrett's-like metaplasia. The K14-CdX2::L2-IL-1 $\beta$ double transgenic mice had half as many metaplastic nodules as control $L 2-I L-1 \beta$ mice. This effect was not due to a reduction in esophageal IL-1 $\beta$ mRNA levels nor diminished systemic inflammation. The diminished metaplasia was due to an increase in apoptosis in the $K 14-C d \times 2:: L 2-I L-1 \beta$ mice. Fluorescence activated cell sorting of immune cells infiltrating the metaplasia identified a population of $\mathrm{CD11}^{+} \mathrm{Gr}^{+} \mathrm{1}^{+}$cells that are significantly reduced in $\mathrm{K14}-$ Cdx2::L2-IL-1 $\beta$ mice. These cells have features of immature granulocytes and have immune-suppressing capacity. We demonstrate that the apoptosis in K14-Cdx2::L2$I L-1 \beta$ mice is $\mathrm{CDB}^{+} \mathrm{T}$ cell dependent, which $\mathrm{CD11b} \mathrm{b}^{+} \mathrm{Gr}-1^{+}$cells are known to inhibit. Lastly, we show that key regulators of $\mathrm{CD11}^{+} \mathrm{Gr}^{+} \mathbf{1}^{+}$cell development, IL-17 and S100A9, are significantly diminished in the esophagus of K14-Cdx2::L2-IL-1 $\beta$ double transgenic mice. We conclude that metaplasia development in this mouse model for Barrett's-like metaplasia requires suppression of CD8+ cell dependent apoptosis, likely mediated by immune-suppressing $\mathrm{CD}_{11} \mathrm{~b}^{+} \mathrm{Gr}-1^{+}$immature myeloid cells.

\section{INTRODUCTION}

Esophageal adenocarcinoma (EAC) is an important cause of death in the US, and one of a few cancers whose incidence is on the rise [1]. EAC develops from a metaplastic, premalignant columnar epithelium known as Barrett's esophagus (BE) rather than the squamous epithelium typically present in the esophagus [2-4]. BE is frequently observed in the setting of chronic gastric acid and bile reflux that results in injury and inflammation. The prevalence of Barrett's is estimated at $10-15 \%$ of patients with gastroesophageal reflux disease (GERD) [5]. Given its prevalence, its association with EAC, and the increasing incidence of EAC, understanding BE pathogenesis is an important clinical and research imperative.
An important focus of our research is the development of novel mouse transgenic models for $\mathrm{BE}$ and EAC. Previously we ectopically expressed $\mathrm{Cdx} 2$, an intestine-specific transcription factor commonly observed in $\mathrm{BE}$, in the mouse esophagus and forestomach using the murine Keratin 14 gene promoter [6]. Cdx2 expression was associated with altered cell morphology and ultrastructure of the esophageal epithelium. In particular we observed dilated intercellular spaces between the squamous basal cells and a compromised epithelial barrier (Figure 1A). However, the formation of a true intestinal metaplasia did not occur.

More recently, a physiologically relevant transgenic mouse model for $\mathrm{BE}$ and $\mathrm{EAC}$ was described by our group [7]. It utilized an Epstein-Barr virus L2 
promoter to over-express human IL-1 $\beta$ in the oral cavity, esophagus, and squamous forestomach of mice. These $L 2-I L-1 \beta$ mice develop a chronic [8] inflammatory esophagitis by 3 months (Figure 1A) that is followed subsequently by the development of a columnar metaplasia with intestinal features that later progresses to dysplasia and cancer. The strength of this transgenic mouse model is that in many ways it strongly phenocopies the pathogenesis of the human Barrett's esophagus as it is presently believed to occur $[4,9]$, with a chronic inflammatory esophagitis preceding the onset of metaplasia, followed subsequently by dysplasia and cancer. Moreover, this disease sequence is accelerated in the $L 2-I L-1 \beta$ mice by the addition of bile acids, as is hypothesized for the human disease. In addition, based on histologic and molecular criteria, the columnar metaplasia which develops in the $L 2-I L-1 \beta$ resembles that of human $\mathrm{BE}$ [7]. Lastly, the metaplasia, dysplasia and cancer arise at the squamo-columnar junction (SCJ) much as in the human disease. Together, these observations all suggest the $L 2-I L-1 \beta$ mouse is an excellent animal model for human BE and EAC. However, there are limitations of this animal model. Anatomically, mice have a squamous forestomach, and therefore this metaplasia arises at the SCJ in the stomach. In addition, although the production of intestinal mucins is strongly observed and consistent with an intestinalized metaplsia, mature goblet cells are not typically seen unless the animals are treated with Notch signaling inhibitors. For this reason, the metaplasia that develops has been described as "Barrett's-like metaplasia" [7].

Given that $\mathrm{Cdx} 2$ is expressed in BE, is required for the intestinal phenotype [10], and that ectopic expression of $\mathrm{Cdx} 2$ in the esophagus induces a barrier dysfunction, we hypothesized that the K14-Cdx2 transgene would synergize with the $L 2-I L-1 \beta$ transgene and promote a more rapid progression to metaplasia and cancer. Unexpectedly, the double transgenic mice had fewer metaplastic nodules at the SCJ compared to the $L 2-I L-1 \beta$ control mice. This was not due to diminished esophagitis or systemic inflammation. The reduction was due to an observed increase in apoptosis in the developing metaplasia at the SCJ of the double-transgenic mice that was not present in the single transgenic controls. Mechanistically, we provide evidence that this apoptosis is immune-mediated and increased due to significant reductions in the levels of an immune-suppressing subpopulation of immature $\mathrm{CD} 11^{+} \mathrm{Gr}-1^{+}$myeloid cells. These $\mathrm{CD} 11^{+} \mathrm{Gr}-1^{+}$cells have been implicated in promoting tumorigenesis in a number of mouse models of cancer [11-13]. We conclude this population of immature myeloid cells with immune suppressor function are critical for disease progression in the $L 2-I L-1 \beta$ transgenic mouse model for $\mathrm{BE}$ and EAC.

\section{RESULTS}

\section{Ectopic Cdx2 expression in murine esophageal epithelium does not alter the inflammatory esophagitis induced by transgenic $I L-1 \beta$ expression}

To investigate for synergy between ectopic esophageal expression of the intestine-specific transcription factor $\mathrm{Cdx} 2(K 14-C d x 2)$ and an animal model for Barrett's-like metaplasia, $L 2-I L-1 \beta$ transgenic mice, we crossed them to yield doubly transgenic K14$C d x 2:: L 2-I L-1 \beta$ mice (Figure 1A). To enhance the onset of metaplasia, we treated all mice in this study with $0.2 \%$ deoxycholic acid treatment (DCA, $\mathrm{pH} 7.0$ ) in the drinking water beginning at 8 weeks of age and continued this treatment for 12 months total (to age 14 months, Figure 1B), as was done in the initial report describing the IL-1 $\beta$ transgenic model for a Barrett'slike metaplasia [7]. Histologic analysis of the esophagus confirmed $\mathrm{Cdx} 2$ protein expression in the basal epithelial cell population of only the K14-Cdx2 and K14-Cdx2::L2$I L-1 \beta$ transgenic lines but not in wild-type littermates or $L 2-I L-1 \beta$ transgenic mice (Figure $1 \mathrm{C}$ ). This indicates that prolonged DCA exposure does not itself induce $\mathrm{Cdx} 2$ expression in the murine esophagus. In both of the K14$C d x 2$ containing lines, $C d x 2$ mRNA levels induced over WT control were no different (400-fold \pm 100 in K14$C d x 2$ mice vs 408 -fold \pm 160 in K14-Cdx2::L2-IL-1 $\beta$ mice; $n=6$ ) and protein expression levels are similarly equivalent by immunohistochemistry and not affected by the $L 2-I L-1 \beta$ transgene (Figure $1 \mathrm{C}$ and $1 \mathrm{D}$ ).

The $L 2-I L-1 \beta$ transgene induces a brisk inflammatory infiltrate in the esophagus, oral cavity, and tongue of both $L 2-I L-1 \beta$ possessing transgenic lines (Figure $2 \mathrm{~A}$ and data not shown). At the SCJ where the metaplasia occurs, the level of inflammation is not significantly different in both IL-1 $\beta$ expressing transgenic lines, based on histopathology scoring by observers blinded to the genotype (Figure 2B). Levels of IL-1 $\beta$ mRNA in the esophagus were not altered by the $K 14-C d x 2$ transgene (122-fold \pm 48 induction over WT controls in $I L-1 \beta$ mice against 116 -fold \pm 54 induction in $K 14-C d x 2:: L 2-I L-1 \beta$ mice ; $n=6$ ) (Figure 2C). Lastly, systemic inflammation induced by IL- $1 \beta$ expression is similarly unaffected by the $K 14-C d x 2$ transgene. Serum levels for IL-1 $\beta$ were below our ability to measure reliably in both $K 14-C d x 2:: L 2-$ $I L-1 \beta$ and $L 2-I L-1 \beta$ mice (data not shown). However, levels of the pro-inflammatory cytokine IL-6, which is required for the $L 2-I L-1 \beta$ metaplasia phenotype [7], were not measurably different in $L 2-I L-1 \beta(33 \pm 11 \mathrm{pg} / \mu \mathrm{l}$; $n=5)$ and $K 14-C d x 2:: L 2-I L-1 \beta$ mice $(36 \pm 7 \mathrm{pg} / \mu \mathrm{l} ; n=6)$ (Figure 2D). Together, these findings strongly suggest the local esophageal as well as systemic inflammatory activities are equivalent in $L 2-I L-1 \beta$ and $K 14-C d x 2:: L 2-$ $I L-1 \beta$ mice, and that the $K 14-C d x 2$ transgene does not appear to affect the inflammatory response. 

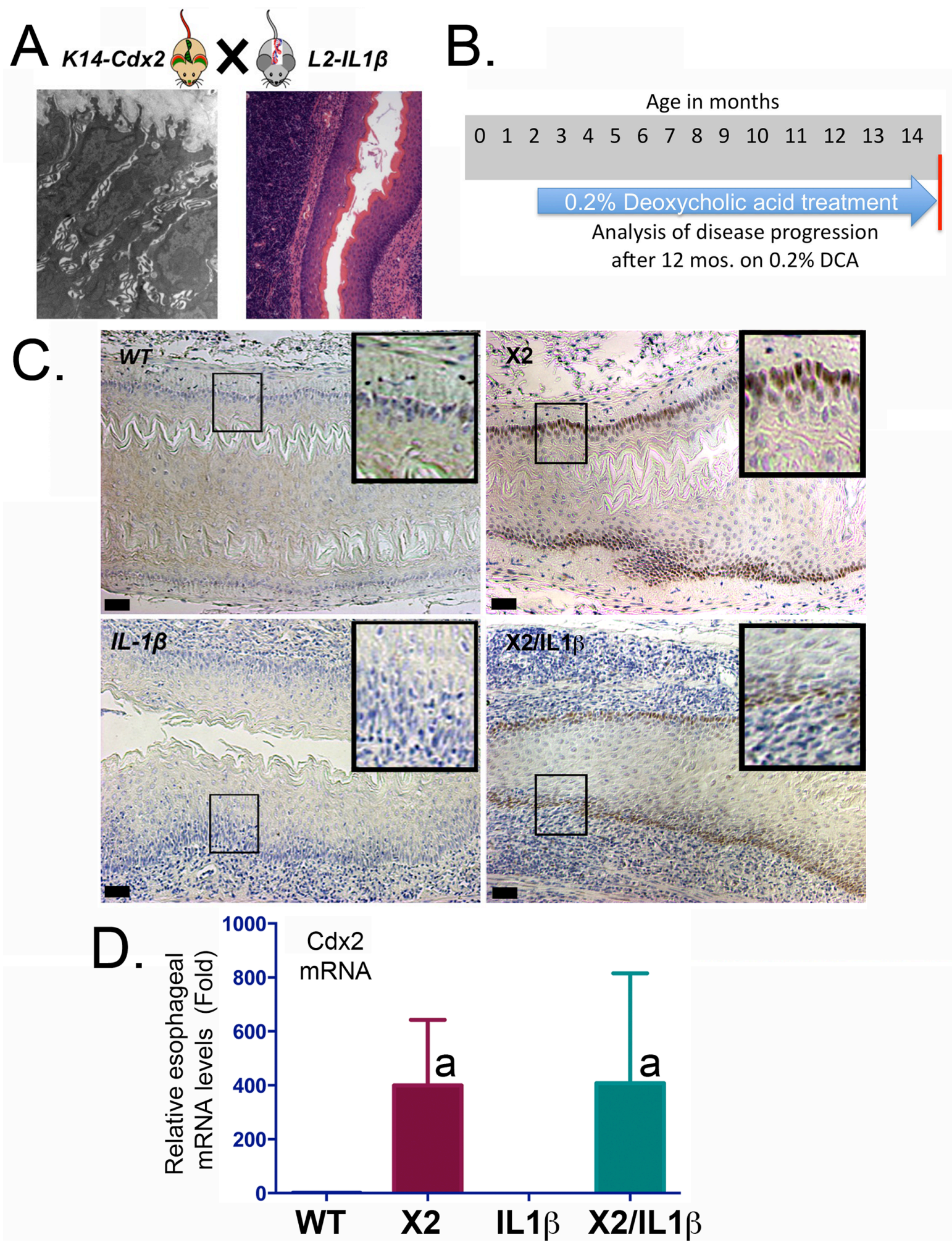

Figure 1: $K 14-C d x 2$ transgene expression is not altered by $L 2-I L-1 \beta$ coexpression in $K 14-C d x 2:: L 2-I L-1 \beta$ mice. A. Model of the crossings to generate $K 14-C d x 2:: L 2-I L-1 \beta$ transgenic mice. TEM image is of dilated intracellular spaces in the esophageal epithelium of K14-Cdx2 transgenic mice. H\&E image is of inflammation in the esophagus of $L 2-I L-1 \beta$ transgenic mice. B. Experimental approach; 8-week old mice were started on $0.2 \%$ DCA in their drinking water and maintained on this for 12 months, at which time the mice were examined for disease extent. C. Representative Immunostaining for Cdx2 expression in esophagi of transgenic mice. (X100

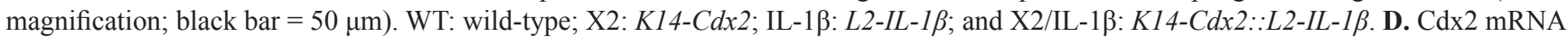
expression by Real-Time PCR analysis for $\mathrm{Cdx} 2 \mathrm{mRNA}$ levels for each group of mice; $(a=$ significantly differs from WT and $I L-1 \beta$ controls by one-sided ANOVA and Tukey Multiple Comparisons testing, adjusted $p<0.047 ; n=6$ ). 

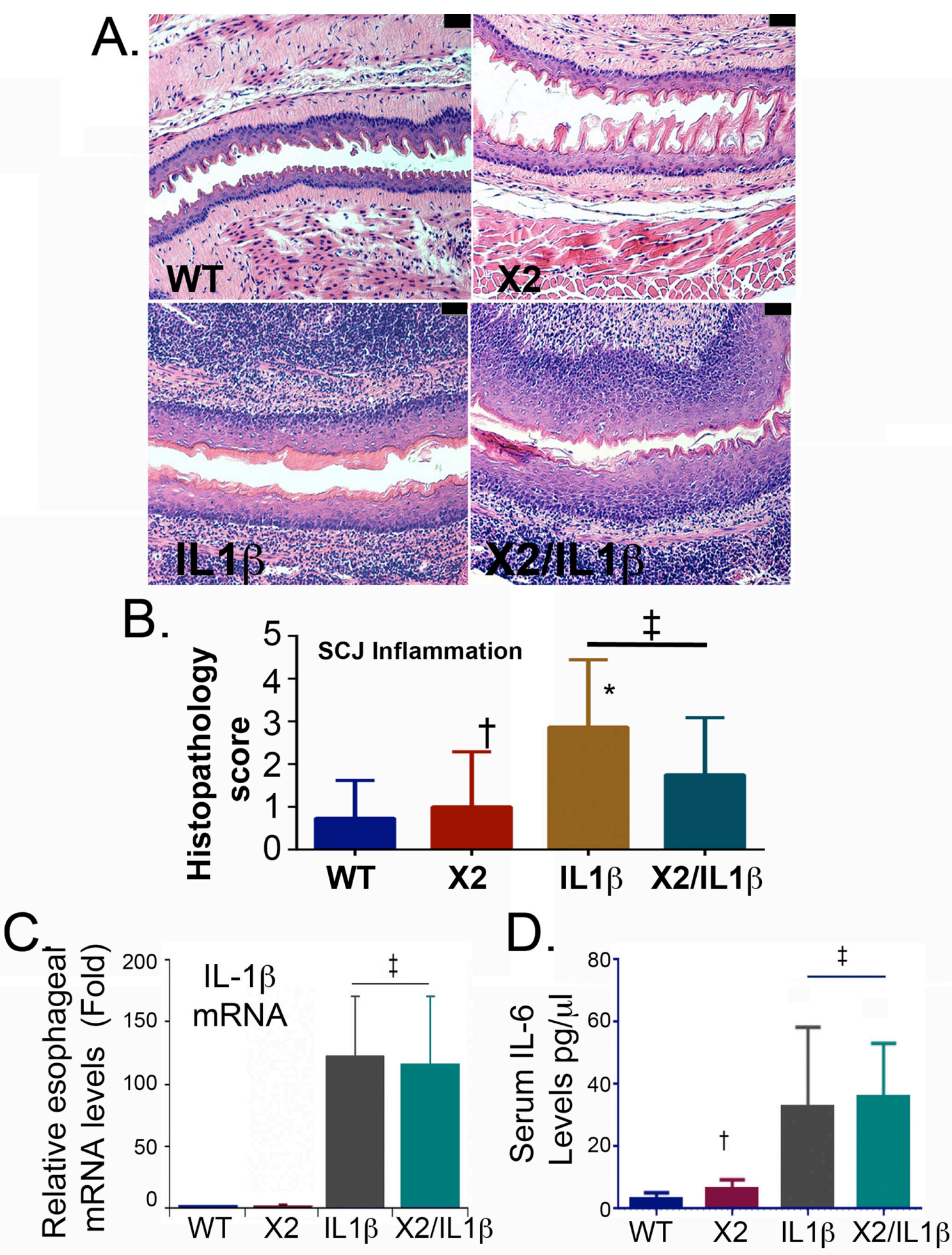

Figure 2: Both $L 2-I L-1 \beta$ and $K 14-C D X 2:: L 2-I L-1 \beta$ mice demonstrate equivalent inflammatory activity. A. Histopathologic alterations in the esophagus of $L 2-I L-1 \beta$ and $K 14-C d x 2: \because L 2-I L-1 \beta$ transgenic mice (X100 magnification; black bar $=50 \mu \mathrm{m}$ ). WT: wild-type; X2:

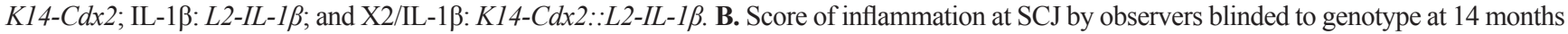
of age. $L 2-I L-1 \beta$ and $K 14-C d x 2: \because L 2-I L-1 \beta$ mice develop increased inflammation that is significant different from WT mice but not different from each other. $\$$ Not significantly different, (adjusted $p=0.40$ ); $\uparrow$ not significantly different from WT control (adjusted $p>0.99$ ); $*$ significantly differs from WT mice (adjusted $p \leq 0.0002$ ) by Kruskal-Wallis ANOVA and Dunn's multiple comparisons testing. C. Determination of esophageal IL-1 $\beta$ mRNA levels by qPCR analysis. Significance determined by one-sided ANOVA and Tukey's Multiple Comparison testing, $n=6$ for each line. († both significantly differ from WT control adjusted $p<0.01$ but no significant difference between $L 2-I L-1 \beta$ and $K 14-C D X 2 / L 2-I L-1 \beta$ mice). D. ELISA for serum levels of IL-6, $n=4$. ( $\dagger$ not significantly different from WT mice by one-sided ANOVA and Tukey Multiple comparisons testing, adjusted $p=0.99$; $\$$ both significantly differ from WT control adjusted $p<0.03$ but no significant difference between each other). 


\section{Ectopic Cdx2 expression in murine esophageal and forestomach epithelium reduces metaplasia development at the squamo-columnar junction in the $I L-1 \beta$ transgenic mice}

At the end of the DCA treatment period, the mice were sacrificed, and the squamo-columnar junctions (SCJ) were examined under a dissecting microscope with a dilute methylene blue stain. A prominent, nodular metaplasia was found at the SCJ in nearly $75 \%$ of the $L 2-I L-1 \beta$ mice $(n=19)$, in keeping with previously reported observations ([7] and Figure 3A and 3B). In the double transgenic $K 14-C d x 2:: L 2-I L-1 \beta$ mice, the nodular metaplasia was similarly observed in nearly $70 \%$ of mice $(n=17)$. Unexpectedly, nearly $20 \%$ of the single transgenic K14$C d \times 2$ mice developed small single nodules at the $\mathrm{SCJ}(n=$ $11)$, much smaller than the disease noted in the $L 2-I L-1 \beta$ and $K 14-C d x 2: \because L 2-I L-1 \beta$ mice. These small nodules were seen only in the $\mathrm{K} 14-C d x 2$ mice receiving DCA in their drinking water (Figure 3B and data not shown).

Despite their similar disease frequencies, K14$C d x 2: \because L 2-I L-1 \beta$ mice appeared to have a reduced burden of nodular metaplasia compared to the $L 2-I L$ $1 \beta$ mice (Figure 3A). To quantify this, we counted the numbers of nodules per mouse, as well as determined the volume of this metaplasia using standard tumor volume approaches. Most significantly, the K14-Cdx2::L2-IL$1 \beta$ mice $(2.2$ nodules/mouse $\pm 2.0 ; n=17)$ had half as many metaplastic nodules as the $L 2-I L-1 \beta$ littermates (4.6 nodules/mouse $\pm 2.4 ; n=19$ ) (Figure 3C). There were no significant differences in the average size of the nodules in the $L 2-I L-1 \beta$ and $K 14-C d x 2:: L 2-I L-1 \beta$ mice (data not shown). However the nodules in both were significantly larger than those observed in the $K 14-C d x 2$ mice (data not shown). Overall, the nodule burden in the $L 2-I L-1 \beta$ mice was greatest, primarily due to the increased numbers of nodules in these mice. In summary, $\mathrm{Cdx} 2$ co-expression with IL-1 $\beta$ reduced the number of nodules of Barrett'slike metaplasia observed in the $L 2-I L-1 \beta$ mice treated with DCA for 12 months.

\section{Apoptosis is significantly increased in the Barrett's- like metaplasia of $K 14-C d x 2:: L 2-I L-1 \beta$ mice}

To understand better what the effects of $\mathrm{Cdx} 2$ coexpression are on the $L 2-I L-1 \beta$ mouse phenotype, we next examined the metaplasia that develops in the K14$C d x 2: \because L 2-I L-1 \beta$ mice. The metaplasia which arises in $L 2-$ $I L-1 \beta$ mice has been previously-described as Barrett's-like based on several criteria, the most importantly being 1) the induction of intestinal mucin-producing cells (but not classic goblet cells), 2) the disease arising in the setting of chronic inflammation at the SCJ (as occurs in the human disease), and 3) a gene expression pattern which significantly overlaps with the human BE disease [7].
As in this published description, there is an expansion of a glandular, columnar epithelium at the SCJ and displacement of the oxyntic gastric glands distally in both the $L 2-I L-1 \beta$ and $K 14-C d x 2: \because L 2-I L-1 \beta$ mice (Figure 4). Histopathologically, this metaplasia was present in both the $L 2-I L-1 \beta$ and $K 14-C d x 2: \because L 2-I L-1 \beta$ mice but not the WT and K14-Cdx2 littermates. In both $L 2-I L-1 \beta$ and $K 14-C d x 2: \because L 2-I L-1 \beta$ mice, the metaplastic cells express intestinal mucins, as evidenced by positive staining with Alcian blue and Muc2 (Figures 5A and 5B). Moreover, consistent with the published report, we can demonstrate increased mRNA expression of the Barrett's esophagus associated genes Cckbr, Tff2, and Krt19 (data not shown). Together these findings confirm the previously published description of the $L 2-I L-1 \beta$ mouse and establish that $K 14-C d x 2$ co-expression does not significantly alter the phenotype of metaplasia which develops in K14$C d x 2: \because L 2-I L-1 \beta$ mice.

We next considered other mechanisms by which $\mathrm{Cdx} 2$ co-expression in the squamous epithelium reduced the development of the nodular metaplasia at the SCJ. $\mathrm{Cdx} 2$ is a transcription factor with tumor-suppressor activity in the intestine, possibly mediated by inhibitory effects on cell proliferation, but it is also reported to have tumorigenic activity by repressing cell apoptosis $[6,14$, $15]$. In the mouse esophagus, IL-1 $\beta$ expression increased cell proliferation equally, as demonstrated by incorporation of the DNA analogue EdU in the Cdx2 non-expressing $(0.29 \pm 0.06 \%$ EdU+nuclei; $n=15$ mice $)$ and expressing $(0.28 \pm 0.07 \% \mathrm{EdU}+$ nuclei; $n=10$ mice $)$ littermates (Figure 6A). At the SCJ, there was no significant effect of either transgene or DCA treatment on SCJ metaplasia EdU incorporation (data not shown), suggesting the observed reduction in metaplastic development in $K 14-C d x 2: \because L 2-$ $I L-1 \beta$ mice was not due to changes in cell proliferation either in the esophagus or at the SCJ.

As an increase in apoptosis in the $\mathrm{K} 14-\mathrm{Cd} 2 \mathrm{2}: \mathrm{L2}$ $I L-1 \beta$ mice could be an explanation, we examined apoptosis rates by Caspase 3 immunohistochemistry (IHC) and TUNEL staining. In the esophagus, there was no evidence that the $L 2-I L-1 \beta$ or $K 14-C d x 2$ transgenes alone altered cellular apoptosis by either technique (Figure 6B and 6C and data not shown). Similarly, there was no significant apoptosis noted in the SCJ metaplasia in $L 2-I L-1 \beta$ transgenic mice (Figure $6 \mathrm{D}$ and $6 \mathrm{~F}$ and F-inset). However, in the K14-Cdx2::L2-IL$1 \beta$ mice, there was a noticeable increase in apoptosis demonstrated by both approaches (Figure 6E and 6G and G-inset). The TUNEL staining in the K14-Cdx2::L2-IL$1 \beta$ mice is localized to nuclei. This is most evident in the inset, and includes many nuclei from the metaplastic glandular epithelium (Figure 6E, 6G, and 6G-inset). In summary, the $\mathrm{K} 14-\mathrm{Cd} \times 2$ transgene limits the formation of the BE like metaplasia in $L 2-I L-1 \beta$ transgenic mice by increasing apoptosis in the developing SCJ metaplasia. 

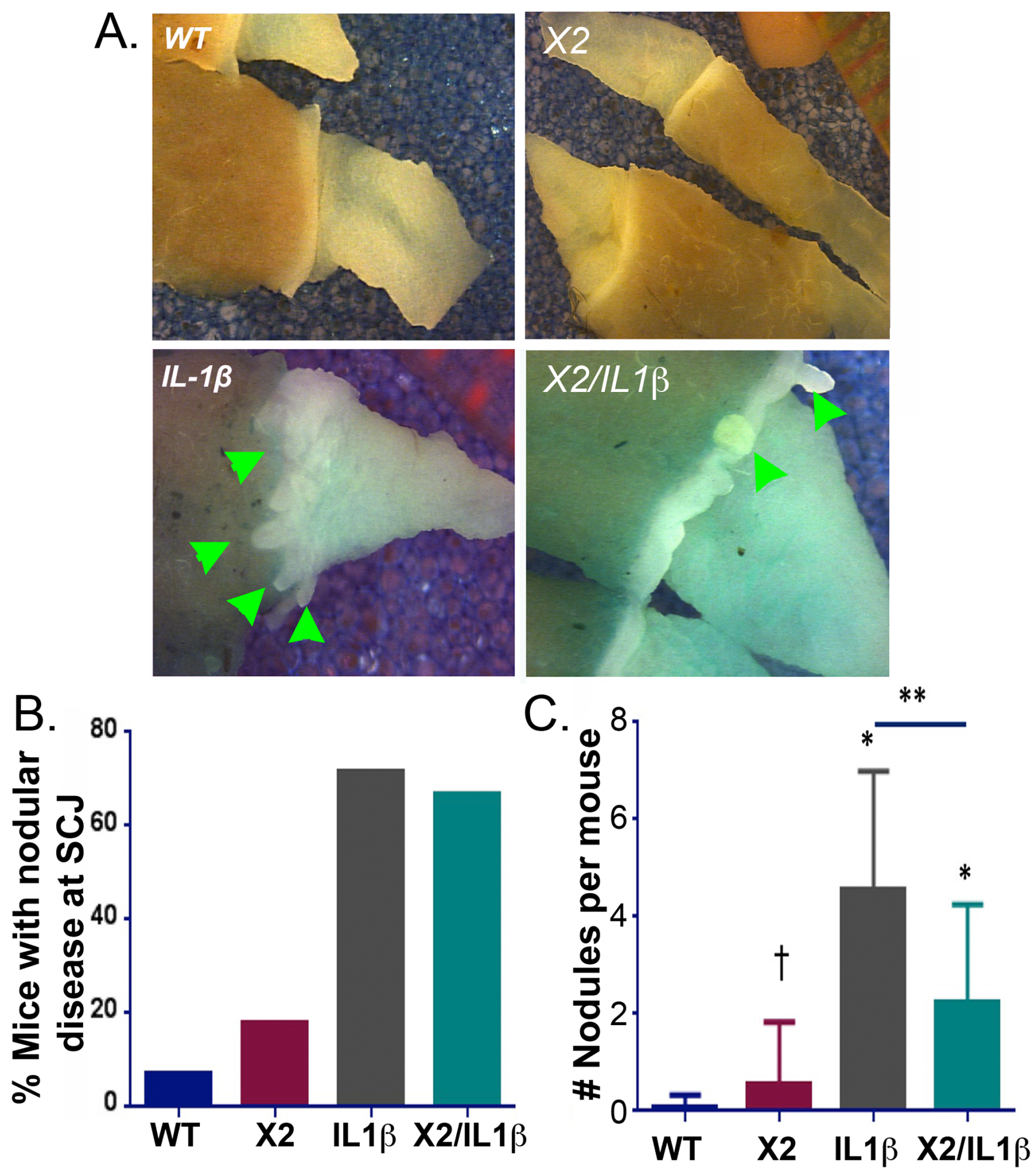

Figure 3: $K 14-C d x 2 / L 2-I L-1 \beta$ TG mice metaplastic nodule numbers and nodule volume are reduced compared to $L 2-$ $\boldsymbol{I L}-1 \boldsymbol{\beta}$ TG mice. A. SCJ nodular metaplasia (Green arrowhead) was present in most of $K 14-C d x 2:: L 2-I L-1 \beta$ and $L 2-I L-1 \beta$ single TG mice by 12 months of DCA treatment distributed along the SCJ of stomach. WT: wild-type; X2: K14-Cdx2; IL-1 1 : L2-IL-1 $\beta$; and X2/IL-1 : $K 14-C d x 2:: L 2-I L-1 \beta$. B. Percentage of mice with nodular metaplasia after 12 months of DCA. WT $n=14 ; K 14-C d x 2 n=11 ; L 2-I L-1 \beta$ $n=19 ; K 14-C d x 2: \because L 2-I L-1 \beta n=17$. C. Average number of nodular metaplastic lesions per mouse; WT $n=14 ; K 14-C d x 2 n=11 ; L 2-I L-1 \beta$ $n=19 ; K 14-C d x 2:: L 2-I L-1 \beta n=17$. Using one-way ANOVA and Tukey's Multiple comparison test ** significantly differs from each other adjusted $p=0.0016$; * Significantly differs from WT mice adjusted $p<0.009$; $\uparrow$ no significant difference between $K 14-C d x 2$ and WT mice adjusted $p=0.9155$. 

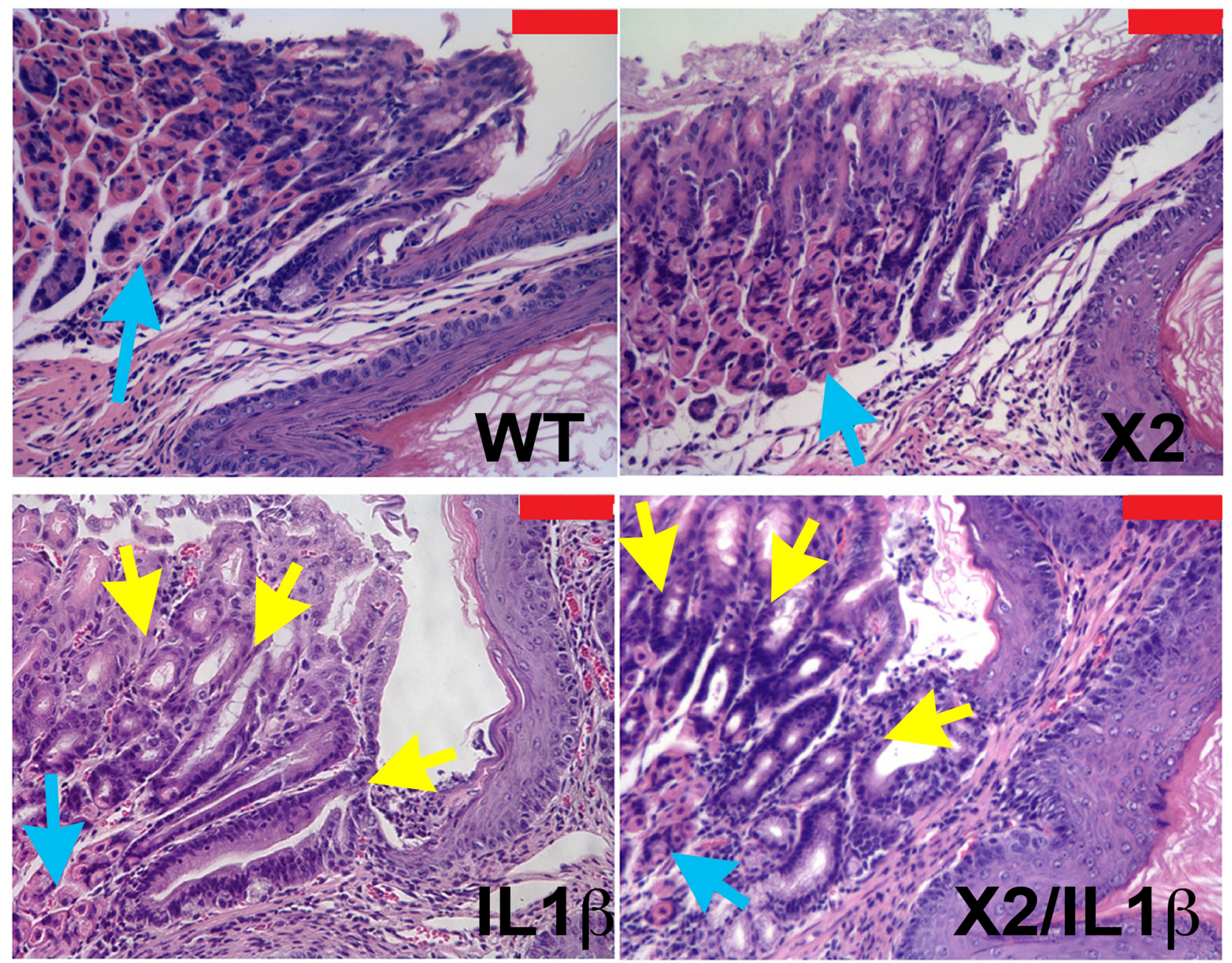

Figure 4: Histopathologic change in $K 14-C d x 2 / L 2-I L-1 \beta$ double and $L 2-L-1 \beta$ single transgenic mice. Histopathologic changes at SCJ area in 12-month DCA-treated mice. (x200 magnification, red bar $=50 \mu \mathrm{m}$ ). Both WT and $K 14-C d x 2$ mice have no significant phenotypic change at the SCJ. $L 2-I L-1 \beta$ and $K 14-C d x 2 / L 2-I L-1 \beta$ mice showed more evident columnar metaplasia with displacement of the oxyntic gastric glands (blue arrow) and expansion of a glandular, columnar epithelium at the SCJ (yellow arrows). WT: wild-type; X2:

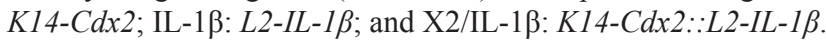

\section{Myeloid cell associated genes are diminished in the metaplastic nodules of $K 14-C d x 2:: L 2-I L-1 \beta$ mice}

In order to determine why cell apoptosis is increased in the developing metaplasia of the double transgenic mice, we performed an Affymetrix microarray analysis of gene expression differences. We compared gene expression in the metaplastic nodules from $L 2-I L-1 \beta$ and $K 14-C d x 2: \because L 2-I L-1 \beta$ mice. We identified 199 genes whose expression differed by 2-fold or more and had less than a 10\% false discovery rate (Table 1 and Supplementary Table S1). Only 47 of the 199 differentially expressed genes had increased levels in the K14-Cdx2::L2-IL-1 $\beta$ mice. The two most strongly induced were Syncollin (Sync) and Cadherin related family member 5 (Cadhr5), both of which are expressed in the intestine and one, Cadhr5, is a known transcriptional target of Cdx2 [16]. A gene function annotation of these 47 genes using DAVID bioinformatic resources [17] found only a few weak associations ( $p$ values between 0.02 and 0.05 ) with early developmental processes (Figure 7A).

A gene ontogeny analysis of genes whose expression was diminished in the double transgenic mice revealed a number of defense and immune response pathways significantly associated ( $p$ values $\geq 0.0005$ ) with the 152 gene list (Figure 7B). In particular, there were several genes reduced whose products are associated with immature myeloid cells, including IL-17a, IL-17c, IL-23a, S100A8, S100A9, and Csf3r (Colony stimulating factor 3 receptorgranulocytes), as well as reductions in Granzyme B and a number of serine proteases suggestive of cytotoxic $T$ cells (Table 1). We had previously established that the inflammation in the esophagus and systemic IL-6 levels were no different between the two transgenic lines. To explore whether the inflammatory infiltrate at the SCJ was diminished in $K 14-C d x 2: \because L 2-I L-1 \beta$ mice, we stained for CD45+ 



Figure 5: Intestinal mucin production by metaplastic glands in $L 2-I L-1 \beta$ and $K 14-C d x 2:: L 2-I L-1 \beta$ transgenic mice. A. Representative pictures of Alcian blue staining in the SCJ metaplasia of 12-month DCA-treated mice. (X100 magnification, red bar $=50$

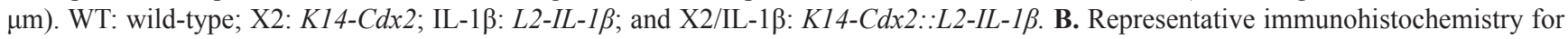
Muc2 expression (brown stain) in the SCJ metaplasia from similar mice (red bar $=50 \mu \mathrm{m}$ ). 


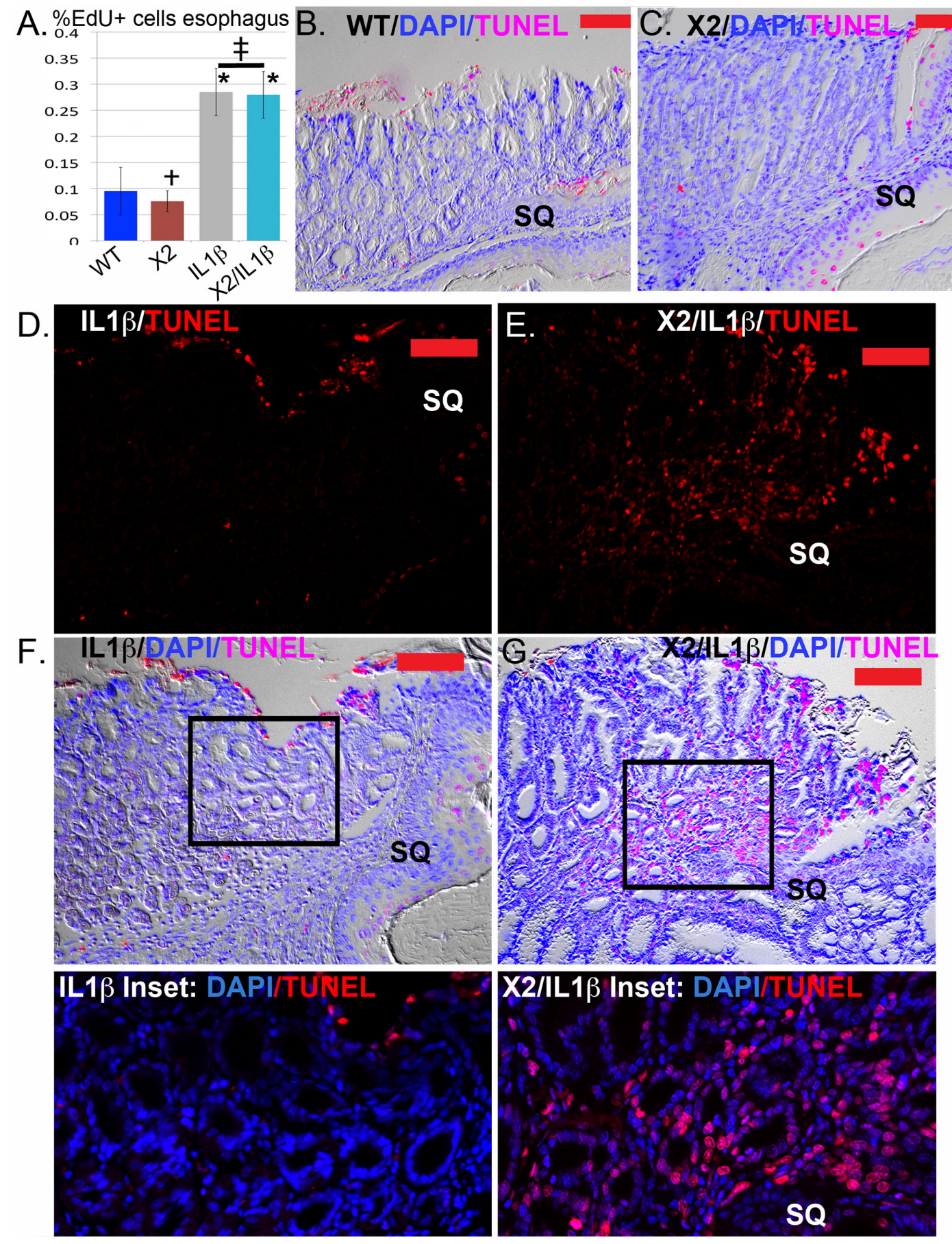

Figure 6: Apoptosis but not cell proliferation is significantly altered in the SCJ metaplasia $K 14-C d x 2:: L 2-I L-1 \beta$ transgenic mice. A. Average counts of EdU incorporation in the esophagi of transgenic and control mice. EdU was detected by Alexa Fluor 594 azide (red) and cell nuclei were stained with DAPI (blue). At least 300 cells per mouse were counted. $L 2-I L-1 \beta$ over-expression promotes cell proliferation in esophageal epithelium. * Significantly differs from control WT mice by one-sided ANOVA and Tukey's Multiple comparison test adjusted $p<0.043$. $\$$ no significant difference between double and single $L 2-I L-1 \beta$ TG mice adjusted $p=0.9996$; $\dagger$ no significant difference between $K 14$ $C d x 2$ and WT mice, adjusted $p=0.9932 . n=15$ mice WT, $n=8$ mice $K 14-C d x 2, n=15$ mice $L 2-I L-1 \beta$, and $n=10 \mathrm{~K} 14-C d x 2:: L 2-I L-1 \beta$ mice. B. and C. Representative imaging of combined nuclear (DAPI-blue), TUNEL (Tetramethylrhodamine -red) and differential interference contrast microscopy (Nomarski) of the SCJ of (B) WT and (C) K14-Cdx2 mice. (x200, red bar $=50 \mu \mathrm{m})$. D. and E. Representative imaging TUNEL (Tetramethylrhodamine-red) staining of the SCJ metaplasia of (D) $L 2-I L-1 \beta$ and (E) K14-Cdx2::L2-IL-1 $\beta$ mice. There is a highly significant increase in TUNEL labeling of the nuclei of the glandular epithelial cells. $(x 200$, red bar $=50 \mu \mathrm{m}$ ). F. and G. Representative imaging of combined nuclear (DAPI-blue), TUNEL (Tetramethylrhodamine -red) and differential interference contrast microscopy (Nomarski) of the SCJ metaplasia of (F) $I L-1 \beta$ and $(\mathrm{G})$ K14-Cdx2::L2-IL-1 $\beta$ mice. $(\times 200$, red bar $=50 \mu \mathrm{m})$. Inset: $\times 400$ magnification of SCJ metaplasia with only nuclear (DAPI-blue) and TUNEL (Tetramethylrhodamine -red) staining illustrate the localization of TUNEL staining to nuclei, including the glandular epithelium of the metaplasia. 


\begin{tabular}{|c|c|c|}
\hline Biological Process & Gene Ontogeny ID & Adjusted P value \\
\hline Response to Steroid Hormone & 0048545 & 0.0279 \\
\hline Trophectoderm Cell Differentiation & 0001829 & 0.0279 \\
\hline Response to Organic Cyclic Compound & 0014070 & 0.0279 \\
\hline Azole Transport & 0045117 & 0.0279 \\
\hline Blastocyst Formation & 0001825 & 0.0319 \\
\hline
\end{tabular}

\begin{tabular}{|c|c|c|}
\hline Biological Process & Gene Ontogeny ID & Adjusted P value \\
\hline Keratinization & 0031424 & 0.000005 \\
\hline Defense Response & 0006952 & 0.0001 \\
\hline Immune System & 0002376 & 0.0001 \\
\hline Multi-organism Process & 0051704 & 0.0002 \\
\hline Regulation of IFN- $\gamma$ Production & 0032649 & 0.0002 \\
\hline Defense Response to Bacterium & 0042742 & 0.0002 \\
\hline IFN-g Production & 0032609 & 0.0002 \\
\hline NK cell Activation & 0030101 & 0.0003 \\
\hline Neutrophil Chemotaxis & 0030593 & 0.0003 \\
\hline Cytokine Production & 0001816 & 0.0003 \\
\hline Serine-type Endopeptidase Activity & 0004252 & 0.0005 \\
\hline Serine Hydrolase Activity & 0017171 & 0.0005 \\
\hline Serine-type Peptidase activity & 0008236 & 0.0005 \\
\hline Peptidase Inhibitor Activity & 0030414 & 0.0014 \\
\hline
\end{tabular}

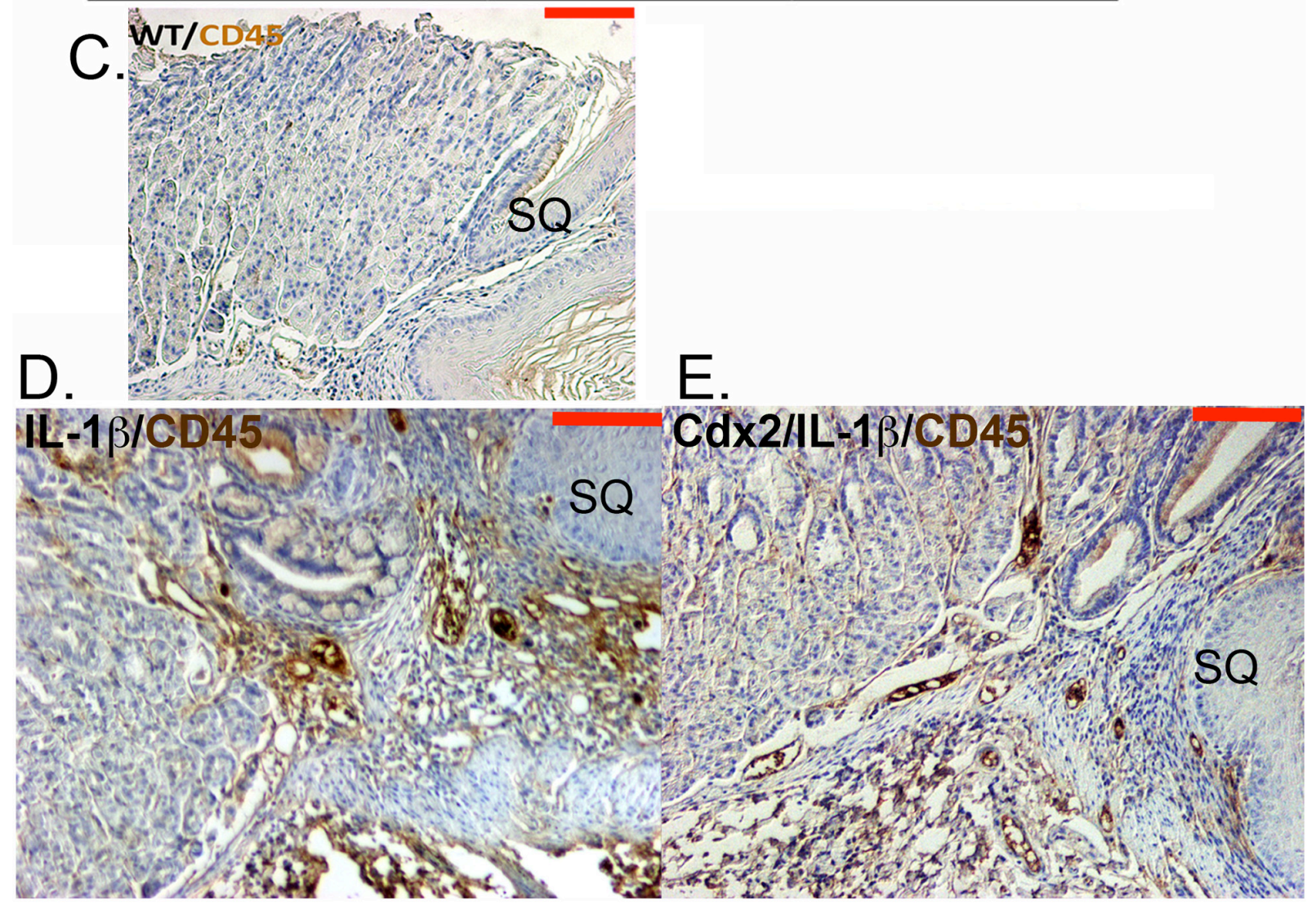

Figure 7: Cdx2 overexpression in $L 2-I L-1 \beta$ transgenic mice leads to downregulated myeloid cell genes in the SCJ metaplastic nodules but no effect on CD45+ cell infiltration. An Affymetrix microarray analysis of gene expression in the SCJ nodules from K14$C d x 2:: L 2-I L-1 \beta$ mice and $L 2-I L-1 \beta$ mice was performed. A. Green box: A partial list of the gene function annotation using DAVID bioinformatic resources of the 47 genes whose expression is increased in $K 14-C d x 2: \because L 2-I L-1 \beta$ mice with a $p<0.05$. B. Red Box: A partial list of the gene ontogeny analysis of the 152 genes diminished in $K 14-C d x 2:: L 2-I L-1 \beta$ mice compared to $L 2-I L-1 \beta$ mice with a $p<0.05$. Green shading highlights immune or inflammation associated processes. C-E. Immunohistochemistry for CD45+ cells at the SCJ from 12-month DCA treated mice. (C) Non-transgenic WT mice, (D) L2-IL-1 $\beta$ mice, and (E) K14-Cdx2::L2-IL-1 $\beta$ mice (X200 magnification, red bar $=50 \mu \mathrm{m}$ ). 
Table 1: Abbreviated list of genes whose mRNA levels were significantly different

\begin{tabular}{|c|c|c|c|}
\hline Gene Symbol & Gene Name & Fold-Change & $p$-value \\
\hline Sycn & Syncollin & 13.5724 & 0.00640984 \\
\hline Cdhr5 & Cadherin-related family member 5 & 7.18268 & 0.0117104 \\
\hline $\mathrm{Cdx} 2$ & Caudal type homeobox 2 & 6.622 & 0.000418314 \\
\hline Ifi2712b & Interferon, alpha-inducible protein 27 like $2 \mathrm{~B}$ & 6.07215 & 0.00849458 \\
\hline Far2 & Fatty acyl CoA reductase 2 & 5.33113 & 0.00304483 \\
\hline Mir145 & mIR-145 & 3.99754 & 0.0115672 \\
\hline Lce1k & Late cornified envelope $1 \mathrm{~K}$ & 3.73066 & 0.0275127 \\
\hline Krt79 & Keratin 79 & 3.71593 & 0.0108772 \\
\hline P2ry2 & Purinergic receptor P2Y, G-protein coupled 2 & -2.08968 & 0.00444745 \\
\hline Pglyrp1 & Peptidoglycan recognition protein 1 & -2.12096 & 0.0136792 \\
\hline $\mathrm{Il} 23 \mathrm{a}$ & Interleukin 23 , alpha subunit p19 & -2.13829 & 0.00144615 \\
\hline Gzmb & Granzyme B & -2.14237 & 0.00477608 \\
\hline Selplg & Selectin, platelet ( $\mathrm{p}$-selectin) ligand & -2.1509 & 0.010656 \\
\hline I127ra & Interleukin 27 receptor, alpha & -2.18232 & 0.000621474 \\
\hline Ptpn22 & Protein tyrosine phosphatase, non-receptor type 22 (lymphoid) & -2.19618 & 0.00301512 \\
\hline Stap 1 & Signal transducing adaptor family member 1 & -2.24255 & 0.0120524 \\
\hline Blk & B lymphoid kinase & -2.29922 & 0.00536239 \\
\hline $\mathrm{Il} 2 \mathrm{rb}$ & Interleukin 2 receptor, beta chain & -2.33622 & $3.26 \mathrm{E}-05$ \\
\hline $\mathrm{Cd} 3 \mathrm{e}$ & CD3 antigen, epsilon polypeptide & -2.44474 & 0.0169952 \\
\hline Nox 1 & NADPH oxidase 1 & -2.61431 & 0.00624271 \\
\hline Mmp9 & Matrix metallopeptidase 9 & -2.62158 & 0.0227285 \\
\hline Clec $4 \mathrm{e}$ & C-type lectin domain family 4 , member e & -2.67522 & 0.00210464 \\
\hline Defb14 & Defensin beta 14 & -2.72681 & 0.0271445 \\
\hline Len2 & Lipocalin 2 & -2.76479 & 0.00137978 \\
\hline Il17c & Iinterleukin $17 \mathrm{C}$ & -2.77006 & 0.050003 \\
\hline Csf3r & Colony stimulating factor 3 receptor (granulocyte) & -2.8235 & 0.0185792 \\
\hline Il17a & Interleukin $17 \mathrm{~A}$ & -2.87594 & 0.00287537 \\
\hline Cxcr6 & Chemokine (C-X-C motif) receptor 6 & -3.08408 & 0.0097923 \\
\hline Pglyrp4 & Peptidoglycan recognition protein 4 & -3.14416 & 0.00447996 \\
\hline Ifitm1 & Interferon induced transmembrane protein 1 & -3.21242 & 0.00218518 \\
\hline $\mathrm{S} 100 \mathrm{a} 8$ & S100 calcium binding protein A8 (calgranulin A) & -3.28772 & 0.000840821 \\
\hline S100a9 & S100 calcium binding protein A9 (calgranulin B) & -3.73631 & 0.000837659 \\
\hline Defb3 & Defensin beta 3 & -3.94574 & 0.000132201 \\
\hline Wfdc12 & WAP four-disulfide core domain 12 & -3.96555 & 0.0344597 \\
\hline Olfm4 & Olfactomedin 4 & -3.96623 & 0.0137842 \\
\hline Ifi202b & Interferon activated gene $202 \mathrm{~B}$ & -5.07291 & 0.00164929 \\
\hline
\end{tabular}

(Continued) 


\begin{tabular}{|c|c|c|c|}
\hline Gene Symbol & Gene Name & Fold-Change & $p$-value \\
\hline Akr1c18 & aldo-keto reductase family 1 , member $\mathrm{C} 18$ & -10.1761 & 0.0246727 \\
\hline Uox & Urate oxidase & -14.9333 & 0.00691962 \\
\hline
\end{tabular}

Determined by Affymetrix microarray analysis of SCJ metaplasia isolated from $K 14-C d x 2: \because L 2-I L-1 \beta$ and $L 2-I L-1 \beta . n=3$ biological replicates for each, with $p \leq 0.05$ for each listed gene.

infiltrating inflammatory cells. We found that both $L 2-I L-1 \beta$ and $K 14-C d x 2: \because L 2-I L-1 \beta$ mice maintained a brisk CD45+ immune cell infiltration at the SCJ junction as compared to normal WT littermates (Figure 7C, 7D, and 7E). Therefore, while the microarray results suggest there may be significant alterations in a subset of myeloid cells in the developing metaplasia, the broader increased inflammatory response is intact in the $K 14-C d x 2:: L 2-I L-1 \beta$ mice.

\section{Immature myeloid cells are diminished in the K14-Cdx2::L2-IL-1ß mice}

To gain a clearer understanding of how the K14$C d x 2$ transgene is altering the nature of the inflammatory response in the $L 2-I L-1 \beta$ mice, we carefully characterized immune cell populations infiltrating the esophagus and SCJ metaplasia by flow cytometry. Levels of T-cells (CD4, CD8), B-cells (B220), dendritic cells (CD11c), natural killer (NK) cells (CD49b) were not altered by the K14-Cdx2 transgene in either the SCJ metaplasia or esophagus (Figure $8 \mathrm{~A}$ and $8 \mathrm{~B} ; n=5$ mice for each genotype, $p>0.05$ ).

There were greater changes in other subpopulations. Cell surface markers for granulocytes (Gr-1) and monocytes (CD11b) appeared to be significantly diminished in the K14$C d x 2: \because L 2-I L-1 \beta$ mice, by 4 to 8 -fold in both the esophagus ( $p=0.049$ and $p=0.053$, respectively $n=5$ mice each genotype) and the SCJ metaplasia ( $p=0.003$ and $p=0.002$, respectively, $n=5$ mice each genotype) (Figure $8 \mathrm{C}$ ), suggesting this effect was systemic and not confined to the SCJ. Both of these markers can also be co-expressed on immature myeloid cell populations [12]. Surprisingly, the majority of $\mathrm{CD} 11 \mathrm{~b}+$ and Gr-1+ cells were in fact double positive, consistent with these cells representing an immature myeloid population (Figure 9). This population was described previously in the $L 2-$ IL-1 $\beta$ mice [7], but their importance for the development of the SCJ metaplasia was not evident. We do not know when these $\mathrm{CD} 11 \mathrm{~b}^{+} \mathrm{Gr}-\mathrm{-}^{+}$cells are first present but we have detected them at 9 months (data not shown) and Quante et. al. reported them in 6 month old mice [7], before the onset of the SCJ metaplasia.

$\mathrm{CD} 11 \mathrm{~b}^{+} \mathrm{Gr}-1^{+}$immature myeloid cells originate in the bone marrow in response to factors secreted by tissues and tumors. They have been implicated in enhancing tumor growth in the breast, colon, and pancreatic cancers [11, 12], but have not been described in precancerous conditions previously. These immature myeloid cells can enhance tumorigenesis by several mechanisms, including inhibition of tumor cell immune surveillance (mediated by cytotoxic T-cells), enhancement of angiogenesis, and the overall promotion of tumor cell survival $[11,12]$. Immature myeloid cells can belong to either the monocytic or granulocytic lineages [18]. To determine which lineage these cells belonged we examined for the expression of Ly-6C and Ly-6G in CD11b+ cells. Monocytic lineages are Ly-6G- $\mathrm{Ly}-6 \mathrm{C}^{\mathrm{Hi}}$ whereas granulocytic lineages are Ly- $6 \mathrm{G}^{+}$and $\mathrm{Ly}-6 \mathrm{C}^{\mathrm{Lo} /}$. We found the $\mathrm{CD} 45^{+} \mathrm{CD} 11 \mathrm{~b}^{+}$cells from esophagus and SCJ metaplasia of the $L 2-I L-1 \beta$ mice were Ly- $6 \mathrm{G}^{+}$and Ly$6 \mathrm{C}^{+}$(Figure 10A, 10B), which is consistent with a granulocytic lineage as previously described [12]. Moreover, these cells are largely lost in the double transgenic $K 14-C d x 2 / L 2-I L-1 \beta$ mice $(n=3$ mice for each genotype) (Figure 10A, 10B). As an additional confirmation of their lineage, we performed intracellular staining for myeloperoxidase (MPO), a lysosomal enzyme abundantly expressed in neutrophil granulocytes. $\mathrm{CD} 45^{+} \mathrm{CD} 11 \mathrm{~b}^{+} \mathrm{Gr}-1^{+}$cells from the SCJ metaplasia strongly express MPO, in contrast to the $\mathrm{CD} 45^{+} \mathrm{CD} 11 \mathrm{~b}^{+} \mathrm{Gr}-1^{-}$and $\mathrm{CD}^{2} 5^{+} \mathrm{CD} 11 \mathrm{~b}^{-} \mathrm{Gr}-1^{-}$populations from the same tissue (Figure 10C). Lastly, immature granulocytes are also known as band cells due to their distinct densely staining and unsegmented nucleus [19]. We isolated $\mathrm{CD} 45^{+} \mathrm{CD} 11 \mathrm{~b}^{+} \mathrm{Gr}-\mathrm{1}^{+}$ cells by FACS, pelleted, fixed, sectioned and stained them for histologic analysis. Morphologically these cells possess the classic prominent, unsegmented nuclei of band cells (Figure 10D), further establishing their identity as an immature granulocytic cell population.

Two key properties of the tumor-promoting $\mathrm{CD}^{2} 5^{+} \mathrm{CD} 11 \mathrm{~b}^{+} \mathrm{Gr}-1^{+}$cell population is that they emerge from the bone marrow, and therefore are a systemic response and not tissue-specific, and that they possess immunesuppressor properties (specifically T-cell suppression) $[12,18]$. To determine if these cells exist beyond the esophagus and SCJ metaplasia, we isolated $\mathrm{CD} 5^{+} \mathrm{CD} 11 \mathrm{~b}^{+} \mathrm{Gr}-1^{+}$cells from the esophagus and the spleen and again assayed for intracellular MPO levels. We observed abundant MPO protein in the $\mathrm{CD} 45^{+} \mathrm{CD} 11 \mathrm{~b}^{+} \mathrm{Gr}-1^{+}$ cell population from both organs, and little MPO in the other control cell populations (Figure 11A and 11B), suggesting they are identical cell types. Moreover, the presence of these cells in the spleen indicates this is a systemic response, not one localized to the esophagus and SCJ metaplasia.

To assay for immune suppressor function in our $\mathrm{CD} 11 \mathrm{~b}+\mathrm{Gr}-1^{+}$cells, we performed an in-vitro $\mathrm{T}$ cell suppression assay. The assay measures the ability of $\mathrm{CD} 45^{+} \mathrm{CD} 11 \mathrm{~b}^{+} \mathrm{Gr}-1^{+}$ cells to suppress $\mathrm{CD}^{+}{ }^{+} \mathrm{T}$-cell proliferation in response to $\mathrm{CD} 3$ / CD28 costimulation [20]. As this assay requires significant numbers of $\mathrm{CD}^{2} 5^{+} \mathrm{CD} 11 \mathrm{~b}^{+} \mathrm{Gr}-1^{+}$cells, they were isolated from the spleens of $L 2-I L-1 \beta$ mice rather than the esophagus or SCJ metaplasia. As can be observed, increasing the ratio of the $\mathrm{CD} 45^{+} \mathrm{CD} 11 \mathrm{~b}^{+} \mathrm{Gr}-\mathrm{1}^{+}$cells to $\mathrm{CD} 4^{+} \mathrm{T}$-cells led to a significant decrease in the proliferative response of the T-cells 

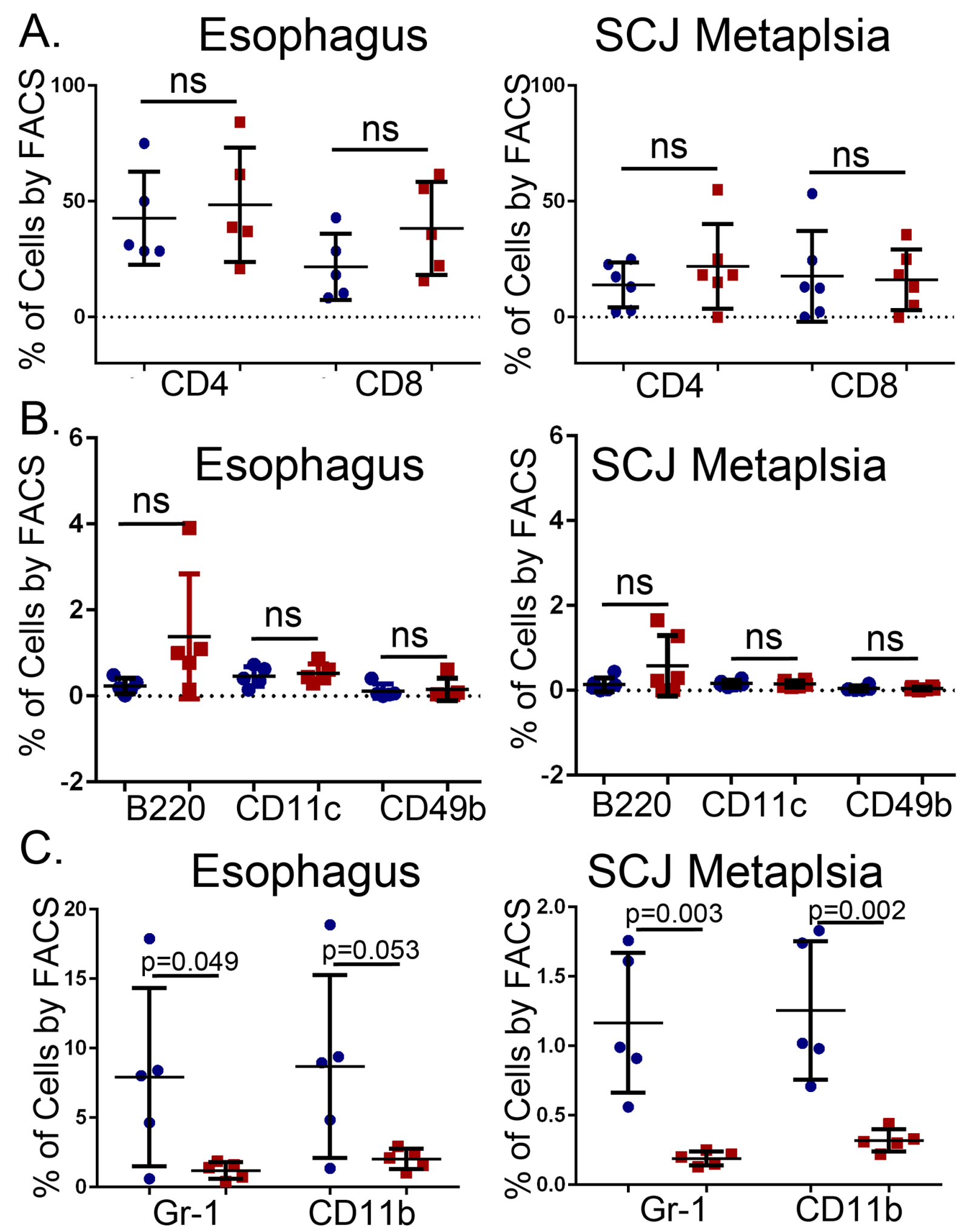

Figure 8: No changes in the numbers of infiltrating T-cells, B-cells, dendritic cells, and natural killer (NK) cells but a reduction in Gr-1+ and CD11b+ cells in the esophagus and SCJ metaplasia of $K 14-C d x 2:: L 2-I L-1 \beta$ transgenic mice. Immune cell subpopulations in the esophagus and the nodular metaplasia were examined by flow cytometry. We quantified levels of T cells $\left(\mathrm{CD}^{+}, \mathrm{CD}^{+}\right)$, B cells $\left(\mathrm{B} 220^{+}\right)$, dendritic cells $\left(\mathrm{CD} 11 \mathrm{c}^{+}\right)$, natural killer $(\mathrm{NK})$ cells $\left(\mathrm{CD} 49 \mathrm{~b}^{+}\right)$, granulocytes $\left(\mathrm{Gr}-1^{+}\right)$and monocytes $\left(\mathrm{CD} 11 \mathrm{~b}^{+}\right)$. All cells were $7 \mathrm{AAD}^{-}$and $\mathrm{CD} 45^{+}$in addition to the specific cell surface marker. A-B. Graphical representation of multiple FACS measures from 5 mice for each cell type. Blue circle: $L 2-I L-1 \beta$ mice. Red squares: $K 14-C d x 2: \because L 2-I L-1 \beta$ transgenic mice. The flow cytometry percentages were Log transformed for statistical analysis ( $p$ values determined by unpaired two-tailed $T$-test, ns : non-significant, $p>0.05$ ). 

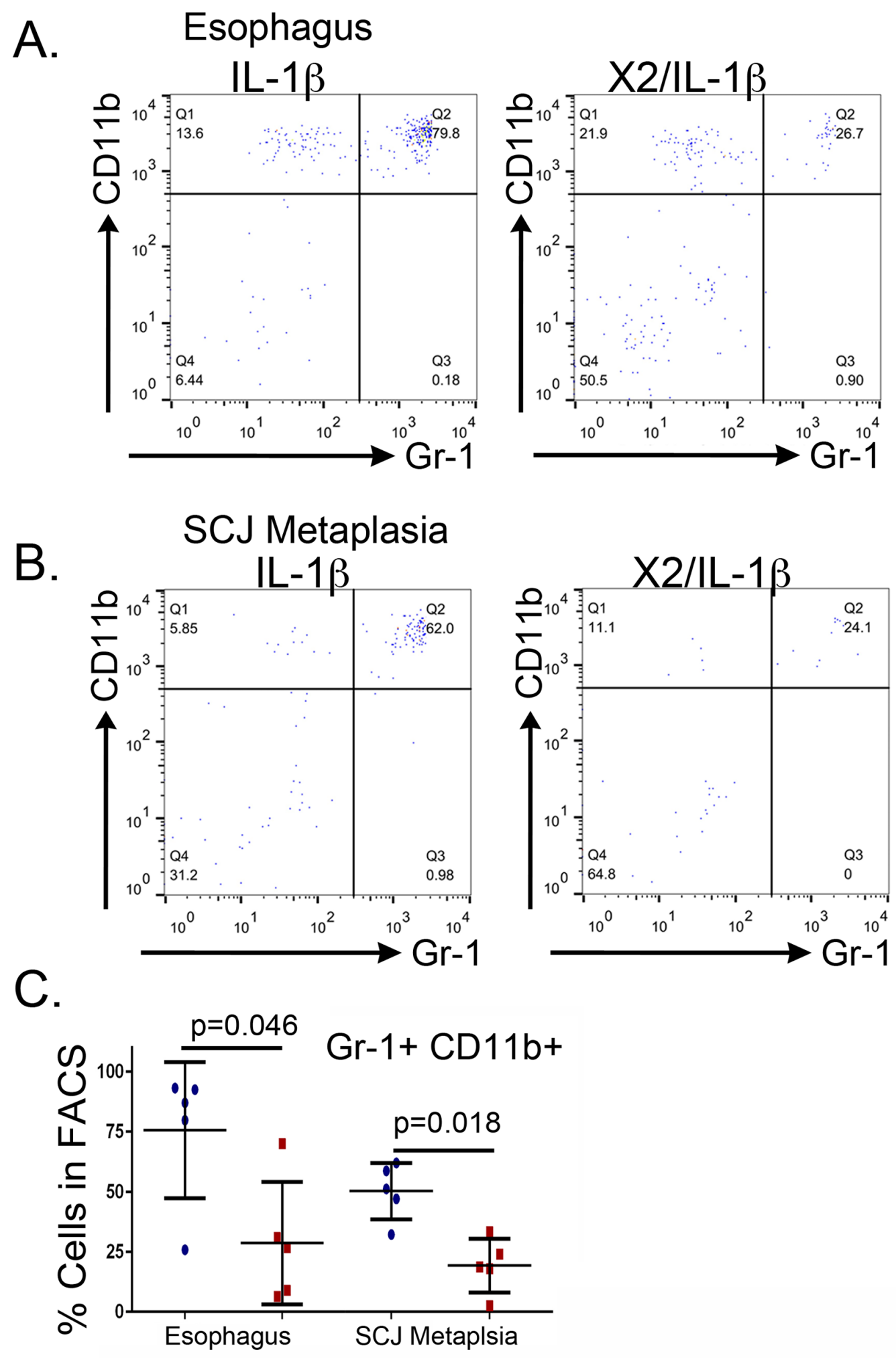

Figure 9: Reduced metaplasia is associated with depletion of $C D 11 b^{+} G r-1^{+}$double-positive cells in the esophagus and SCJ metaplasia of $K 14-C d x 2:: L 2-I L-1 \beta$ transgenic mice. We quantified levels of the double-positive $C D 11 b^{+} \mathrm{Gr}-1^{+}$in the esophagus and SCJ metaplasia. All cells were $7 \mathrm{AAD}^{-}$and $\mathrm{CD}^{4} 5^{+}$in addition to the specific cell surface marker. A, B. A sample FACS experiment demonstrating the significant reduction in $\mathrm{CD}_{11} \mathrm{~b}^{+} \mathrm{Gr}-1^{+}$double positive cells within the infiltrating $\mathrm{CD} 45^{+}$population of the (B) esophagi and C. SCJ metaplasia of $K 14-C d x 2:: L 2-I L-1 \beta$ mice when compared to $L 2-I L-1 \beta$ mice, one of 5 experiments shown. (C) Graphical representation of multiple FACS measures from the esophagus and SCJ metaplasia of 3 to $5 L 2-I L-1 \beta$ and $K 14-C d x 2:: L 2-I L-1 \beta$ mice each. Blue circle: $L 2-I L-1 \beta$ mice. Red squares: $K 14-C d x 2: \because L 2-I L-1 \beta$ transgenic mice. The flow cytometry percentages were Log transformed for statistical analysis ( $p$ values determined by unpaired two-tailed $T$-test, ns : non-significant, $p<0.05$ ) and graphing. 


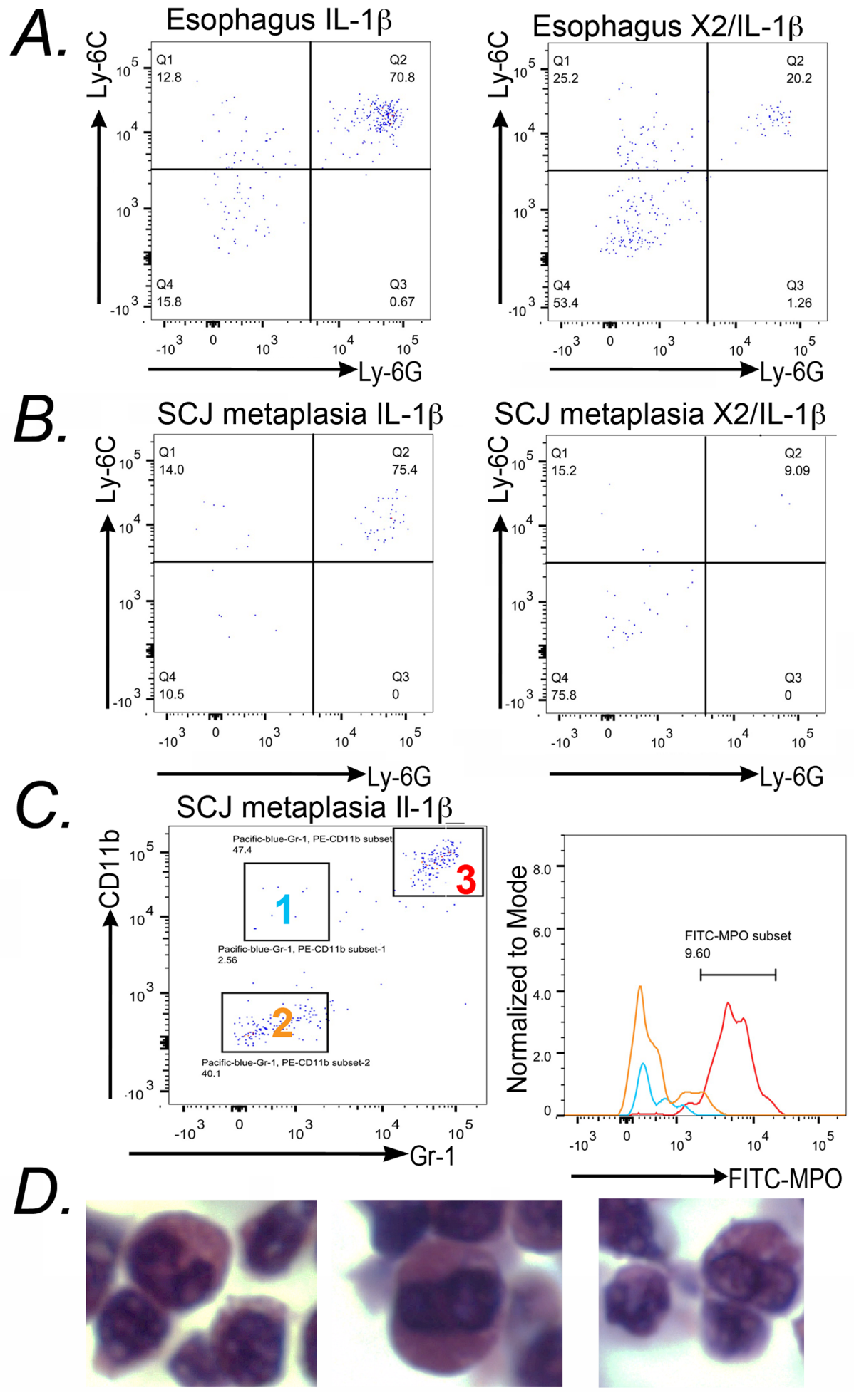

Figure 10: CD11b+/Gr-1+ cells from L2-IL-1 $\beta$ mice express cell surface and intracellular markers that identify them as immature granulocytes. A. $7 \mathrm{AAD} \mathrm{CD}^{-} 5^{+} \mathrm{CD} 11 \mathrm{~b}^{+}$cells from the esophagus were stained with anti-Ly- $6 \mathrm{G}$ and anti-Ly- $6 \mathrm{C}$ for FACS analysis. The majority of CD11b+ cells are positive for both antigens. $n=3$ mice studied. B. Similar findings in the FACS analysis for Ly-6G and Ly-6C expression in $7 \mathrm{AAD} \mathrm{CD}^{-} 5^{+} \mathrm{CD} 11 \mathrm{~b}^{+}$cells isolated from the SCJ metaplasia of $L 2-I L-1 \beta$ and $K 14-C d x 2:: L 2-I L-1 \beta$ mice. As before, the majority of $\mathrm{CD} 11 \mathrm{~b}+$ cells are $\mathrm{Ly}-6 \mathrm{G}^{+} / \mathrm{Ly}-6 \mathrm{C}^{+}$and the levels of these double-positive cells are diminished in the SCJ metaplasia of $K 14-C d x 2:: L 2-I L-1 \beta$ mice. $n=3$ mice studied. C. Dot-plots from FACS analysis indicated 3 subpopulations of $\mathrm{CD}^{+} 5^{+}$cells with anti-CD11b and anti-Gr-1 staining. Relative intracellular staining for MPO in each subset of cells was determined and plotted on a histogram. Plots represent the intracellular staining of MPO in Group $1\left(\mathrm{CD} 45^{+} \mathrm{CD} 11 \mathrm{~b}^{+} \mathrm{Gr}-1^{-}\right.$cells: Blue line), Group $2\left(\mathrm{CD} 45^{+} \mathrm{CD} 11 \mathrm{~b}-\mathrm{Gr}-1^{-}\right.$: Yellow line) and Group $3\left(\mathrm{CD} 45^{+} \mathrm{CD} 11 \mathrm{~b}^{+} \mathrm{Gr}-1^{+}:\right.$Red line). $n=3$ mice studied. D. Hematoxylin and Eosin staining of pelleted $7 \mathrm{AAD}^{-} \mathrm{CD} 45^{+} \mathrm{Gr}-1^{+} \mathrm{CD} 11 \mathrm{~b}^{+}$cells isolated from an $L-2-I L-1 \beta$ transgenic mouse. 


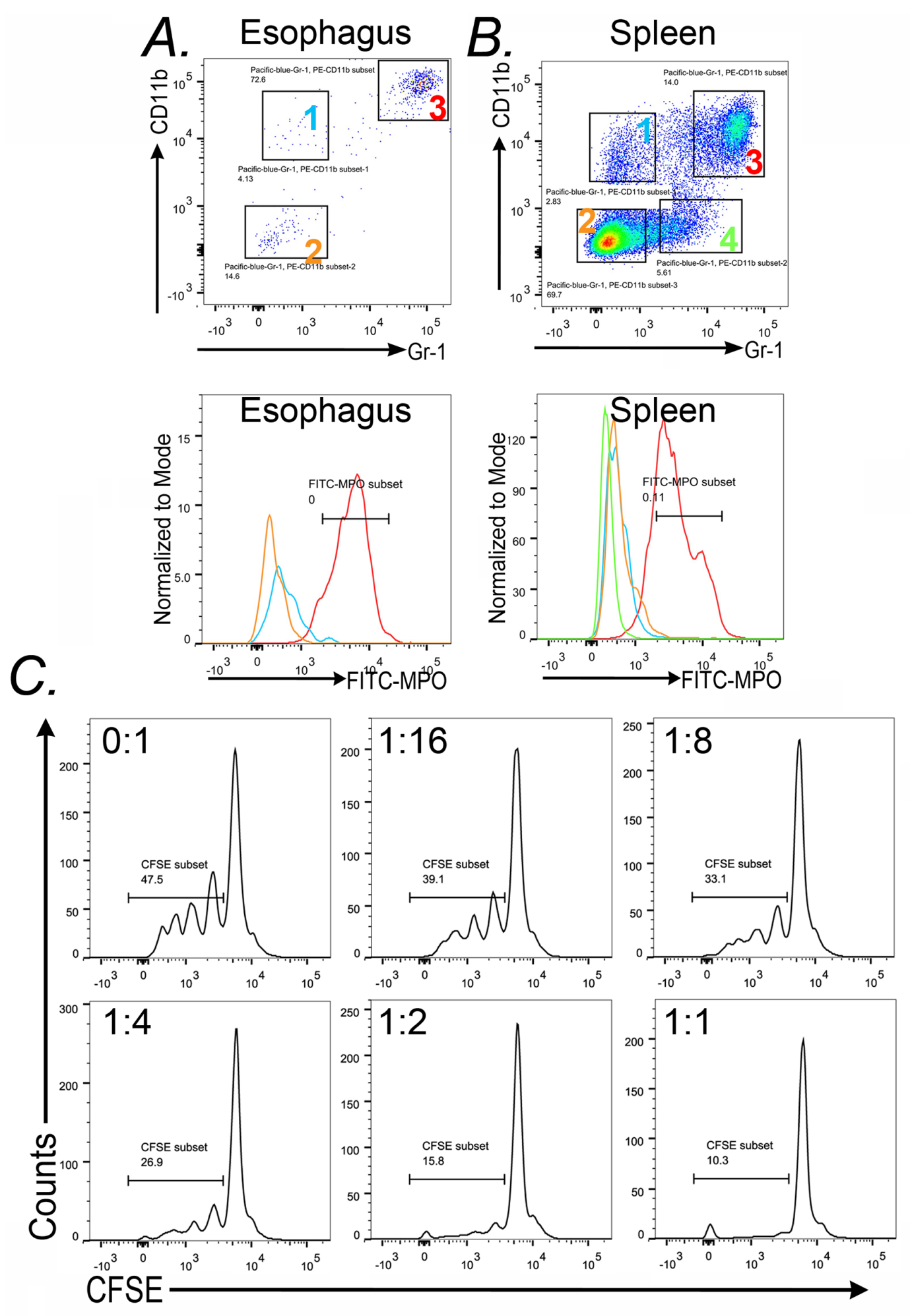

Figure 11: $C D 11 b^{+} G r-1^{+}$from the spleen and esophagus of $L-2-I L-1 \beta$ mice also express MPO+ (Myeloperoxidase) and can suppress CD4+ T-cell proliferation. Dot-plots from FACS analysis of A. esophagi and B. spleen of $L 2-I L-1 \beta$ mice illustrate the gating of the subpopulations analyzed. In the esophagus there are three populations-group 1 (blue): $\mathrm{Gr}-1^{-} \mathrm{CD} 11 \mathrm{~b}^{+}$, group 2 (yellow): Gr- $1^{-} \mathrm{CD} 11 \mathrm{~b}^{-}$and group 3 (Red): $\mathrm{CD} 11 \mathrm{~b}^{+} \mathrm{Gr}-1^{+}$. FACS analysis for spleen tissue indicated 4 subpopulations including the same three as in the esophagus plus Group 4 (green) $\mathrm{Gr}-1^{+} \mathrm{CD} 11 \mathrm{~b}^{-}$. Histogram plots represent the expression of MPO on the gated subsets Group 1 (Blue), Group 2 (Yellow), Group 3 (Red), and Group 4 (green). C. Splenocytes from wild-type C57B16 mice were prelabeled with CSFE and then cultured with anti-CD3/CD28 beads and increasing numbers of Gr- $1^{+} \mathrm{CD} 11 \mathrm{~b}^{+}$cells from $L 2-I L-1 b$ transgenic mice. Ratio progressed from 0 $\left(\mathrm{CD} 11 \mathrm{~b}^{+} \mathrm{Gr}-1^{+}\right.$cells) : 1 (splenocytes) to as high as 1:1. $\mathrm{CD} 4^{+}$cell proliferation was determined by measuring cellular CFSE levels in $\mathrm{CD}^{+} /$ $\mathrm{CD} 4+$ cells after 72 hours. Results from one of four experiments is shown. 
to costimulation by CD3/CD28 beads (Figure 11C). Together, these observations suggest that the $\mathrm{CD} 45^{+} \mathrm{CD} 11 \mathrm{~b}^{+} \mathrm{Gr}-1^{+}$cells, which are significantly reduced in the $K 14-C d \times 2 / L 2-I L-1 \beta$ mice, are immature granulocytes with an immune-suppressor

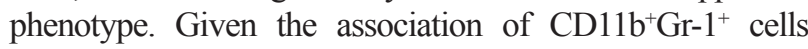
with increased tumor growth in a number of mouse models of cancer, it raises the possibility that these cells may also contribute to metaplasia formation and expansion in the $L 2-I L$ $1 \beta$ mouse model of Barrett's-like metaplasia.

\section{$\mathrm{CD8}^{+}$cells are required for the increased apoptosis in the SCJ metaplasia of the $K 14-C d x 2 / L 2-I L-1 \beta$ mice}

Studies using both mouse cancer models and human subject samples have indicated that increased levels of immature myeloid cells can suppress normal $\mathrm{CD}^{+}$cytotoxic $\mathrm{T}$-cell responses and thereby enhance tumor growth $[11,12,20]$. To determine if $\mathrm{CD}^{+} \mathrm{T}$-cells are involved in the induction of apoptosis observed in the metaplasia of $K 14-C d x 2: \because L 2-I L-1 b$ mice, we targeted CD ${ }^{+}$ cells using an antibody. 14 month-old K14-Cdx2::L2-IL$1 b$ mice were injected with $200 \mu \mathrm{g}$ of anti-mouse CD8 antibody or an isotype control antibody on days 1, 3, and 5 and sacrificed on day 6. FACS analysis of immune cell populations in the spleen, blood and esophagus demonstrated a nearly complete absence of $\mathrm{CD} 8^{+}$cells in the mice receiving the anti-CD8 antibody and not those mice receiving the isotype control (Figure 12). Moreover, $\mathrm{CD}^{+} \mathrm{T}$ cell levels were not affected by either treatment, attesting to the specificity of the ablation.

We then assessed the SCJ metaplasia for histologic changes with the $\mathrm{CD}^{+}$cell knockdown. Since the $\mathrm{CD}^{+}$ cell knockdown was a short duration, we did not observe significant changes in metaplasia abundance or morphology (data not shown). Significantly, however, there was a near complete loss of the apoptosis previously observed at the

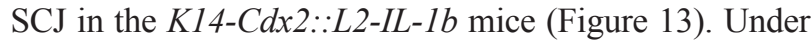
closer examination, it can be observed that the apoptosis is reduced in the squamous forestomach as well as the adjacent SCJ metaplasia (Figure 13 inset). We conclude that the elevated apoptosis in the squamous forestomach and SCJ metaplasia of the $K 14-C d x 2: \because L 2-I L-1 b$ mice is due to an immune-mediated and CD8+ T-cell dependent mechanism in the $L 2-I L-1 \beta$ transgenic mouse model.

\section{K14-Cdx2::L2-IL-1b mice have diminished expression of known regulators of $\mathrm{CD}_{11 b^{+}} \mathrm{Gr}-1^{+}$ cell development}

We next considered how the development and localization of CD $11 \mathrm{~b}^{+} \mathrm{Gr}-1^{+}$cells were inhibited in the $\mathrm{K} 14$ $C d x 2: \because L 2-I L-1 \beta$ mice. We re-examined the microarray data and identified cytokines IL-17a and $17 \mathrm{c}$, and the immune modulatory S100A8 and S100A9 (Calgranulin-A and B) as being significantly diminished in the SCJ metaplasia (Table 1). All three factors have been demonstrated as key regulators promoting the development and release of immature myeloid $\mathrm{CD}_{1} 1 \mathrm{~b}^{+} \mathrm{Gr}-1^{+}$lineage from the bone marrow $[18,21,22]$. Moreover, three of them, IL$17 \mathrm{c}, \mathrm{S} 100 \mathrm{~A} 8$ and S100A9, are known to be expressed by squamous epithelium including the esophagus [23-27]. Quantitative PCR analysis of the expression of these genes in $L 2-I L-1 \beta$ and $K 14-C d x 2: \because L 2-I L-1 \beta$ mice confirms a strong reduction of their mRNA levels in both the esophagus and SCJ nodular metaplasia in $K 14-C d x 2:: L 2-I L-1 \beta$ mice (Figure 14A). IL-17a mRNA levels were most significantly reduced, by 6 -fold ( $p=0.013$ and $=0.036$, respectively; $n=3$ ), while IL-17c levels were reduced by $60 \%$ to $50 \%$ of control levels $(p=0.036$ and $=0.164 ; n=3)$, and S100A9 mRNA levels were reduced by 5 and 2-fold, respectively $(p=0.018$ and $=0.049 ; n=3)$. In support of this, we performed immunohistochemistry for S100A9 protein in the esophagi from both $L 2-I L-1 \beta$ and $K 14-C d x 2: \because L 2-I L-1 \beta$ transgenic mice. S100A9 protein is detected more abundantly in the squamous epithelium of $L 2-I L-1 \beta$ when compared to $K 14-C d x 2: \because L 2-I L-1 \beta$ mice (Figure $14 \mathrm{~B}$ ). Additionally, S100A9 expressing cells were also much more abundant in the inflammatory cells infiltrating the submucosa of the $L 2-$ $I L-1 \beta$ mice than the $K 14-C d x 2: \because L 2-I L-1 \beta$ transgenic mice. Together with the qPCR data, we conclude that IL-17 and $\mathrm{S} 100 \mathrm{~A} 8 / \mathrm{A} 9$ expression is diminished in the esophagi of K14$C d x 2:: L 2-I L-1 \beta$ transgenic mice. Moreover, it suggests that the observed reduction in metaplasia development at the SCJ of $K 14-C d x 2: \because L 2-I L-1 \beta$ mice may be due to this diminished expression, as these proinflammatory signals are known to be required for the emergence of the CD8-suppressing $\mathrm{CD} 11 \mathrm{~b}+\mathrm{Gr}-1^{+}$immature myeloid cells $[18,21,22]$.

\section{DISCUSSION}

Our understanding of the mechanisms driving the development of Barrett's esophagus and its progression to esophageal adenocarcinoma has been limited by the paucity of animal models of these conditions. The development of the $L 2-I L-1 \beta$ transgenic mouse model for intestinal metaplasia [7] has been a significant advance, and the studies we report here demonstrate the importance of animal models in advancing our understanding of disease mechanisms. Currently, the pathogenesis of Barrett's esophagus is thought to be a response to the chronic inflammation and injury from repeated gastric acid and bile acid reflux into the esophagus $[4,28]$. The strength of the $L 2-I L-1 \beta$ transgenic mouse as a model of $\mathrm{BE}$ and progression to $\mathrm{EAC}$ is that it is 1) dependent upon chronic esophageal inflammation, 2) that the metaplasia, which mimics $\mathrm{BE}$ at the level of morphology and gene expression, occurs at the SCJ as it does in BE, and 3) that bile acids can both accelerate disease progression and enhance intestinalization. Given this strength, our studies which elucidate a novel mechanism driving the onset of the metaplasia in these mice takes on even greater 


\section{A. Isotype Control}
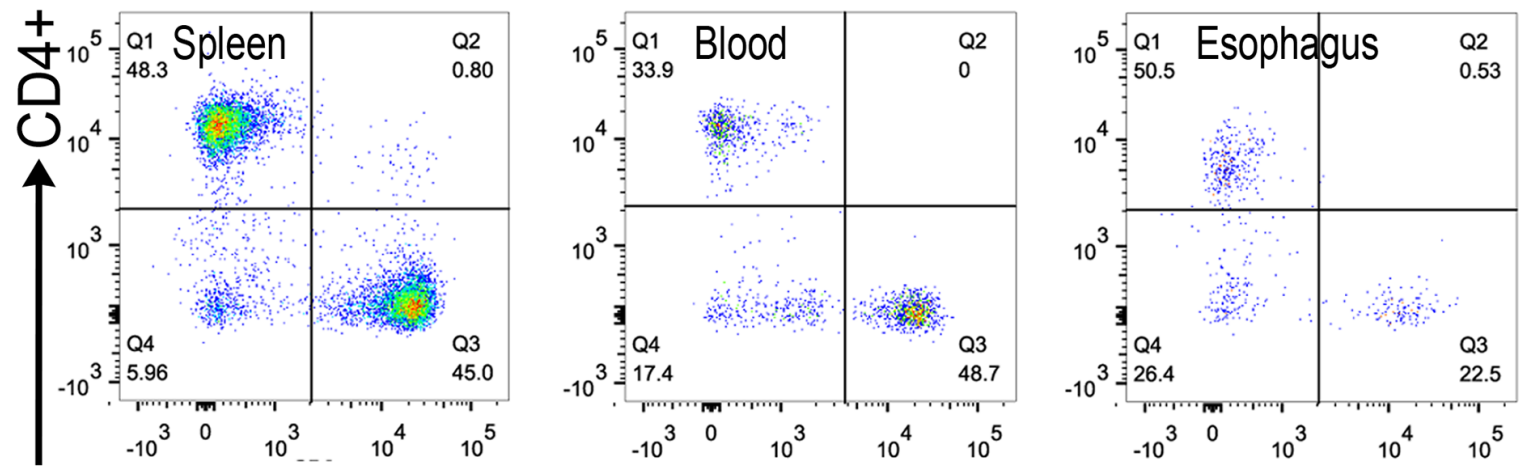

CD8

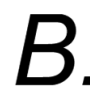

Anti-CD8 antibody
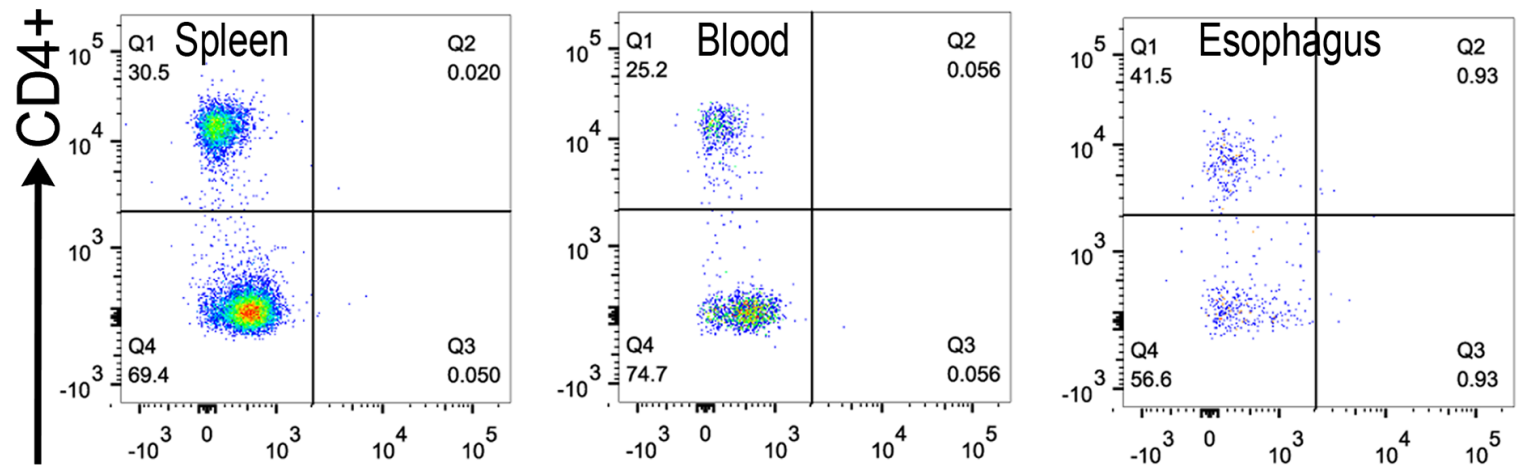

CD8

Figure 12: Antibody-mediated knockdown of CD8+ cells in $K 14-C d x 2 / L 2-I L-1 \beta$ double transgenic mice. $K 14-C d x 2:: L 2-$ $I L-1 \beta$ mice after 12 months of DCA treatment were subject to three injections with an anti-CD8 antibody or an isotype antibody control. Dot-plots from FACS analysis for $\mathrm{CD} 45^{+} \mathrm{CD} 8^{+}$cells in the spleen, blood, and esophagus of $\mathbf{A}$. isotype control and $\mathbf{B}$. anti-CD8 antibody treated $K 14-C d x 2: \because L 2-I L-1 \beta$ mice. There was significant reduction in CD45+CD $8^{+}$cells in all three tissues without an appreciable effect on $\mathrm{CD}^{+} \mathrm{T}$-cells in those same tissues. $n=3 \mathrm{~K} 14-C d x 2: \because L 2-I L-1 \beta$ mice for each condition, 6 mice total.

significance, providing new avenues of exploration for the human disease.

It is interesting to note that although conceptual models for the development of BE have for many years emphasized the role of reflux injury and inflammation in the development of the metaplasia, surprisingly few studies have deeply explored the inflammation and inflammatory cells associated with disease onset and progression. Proinflammatory cytokines including IFN- $\gamma$, IL-1 $\beta$, IL-6, and IL-8, are expressed by epithelial cells in response to acid and bile reflux and drive the influx of a variety of proinflammatory cells including neutrophils, eosinophils, mast cells, macrophages as well as the adaptive immunity $\mathrm{T}$ and $\mathrm{B}$ cells $[29,30]$. In the esophagus, activation of a $T_{H} 1$ pro-inflammatory response, characterized by production of interferon (IFN)- $\gamma$, is typical for acid reflux esophagitis [31]. Progression to BE is accompanied by a shift in cytokine expression patterns, including increased levels of interleukin IL-4, IL-5, IL-10, and IL-13, which are hallmarks of a $\mathrm{T}_{\mathrm{H}} 2$ humoral immune response [31-33]. Associated with this shift in cytokine patterns is a change in the infiltrating immune cells, with a reduction in macrophages in favor of $\mathrm{T}_{\mathrm{H}} 2$ associated plasma cells [34]. More recently, it was demonstrated that myeloid and plasmacytoid dendritic cells are recruited during the esophageal metaplasia-dysplasia-carcinoma sequence [35]. In the same report, it was demonstrated that cordblood derived myeloid dendritic cells, when co-cultured with Barrett's esophagus and esophageal adenocarcinoma cell lines, displayed an immune tolerogenic behavior. This has direct bearing on our novel and important findings.

In humans, $\mathrm{Cdx} 2$ is expressed in $\mathrm{BE}$ and can be detected very early in the disease process, in the setting of reflux esophagitis [36, 37]. We anticipated that crossing 

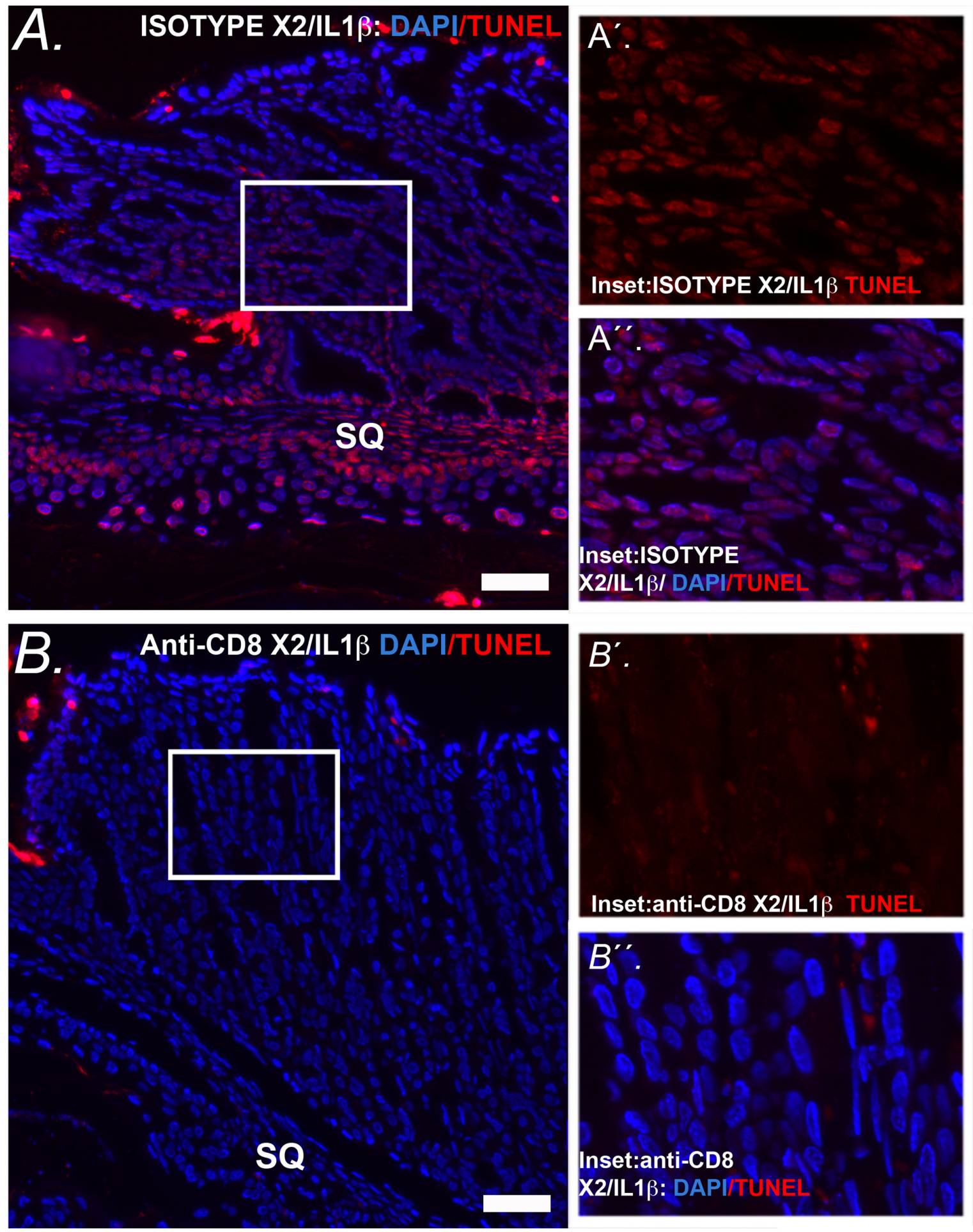

Figure 13: Apoptosis at the SCJ in K14-Cdx2::L2-IL-1ß mice is lost with knockdown of CD8+ cells. A. Representative image of combined nuclear (DAPI-blue) and TUNEL (Tetramethylrhodamine -red) at the SCJ of isotype treated K14-Cdx2::L2-IL-1 $\beta$ mice. (x200, white bar $=50 \mu \mathrm{m}) \mathrm{SQ}=$ squamous forestomach. $\mathbf{A}^{\prime}$ inset. Representative higher-power imaging for TUNEL staining of the apoptotic columnar metaplasia at the SCJ. A" inset. similar higher-power imaging for nuclei (DAPI-blue) and TUNEL (Tetramethylrhodamine -red). There is a highly significant TUNEL labeling of the nuclei of the glandular epithelial cells of isotype treated $K 14-C d x 2: \because L 2-I L-1 \beta$ mice $n=3 K 14-C d x 2: \because L 2-I L-1 \beta$ mice for each treatment. B. Representative imaging of combined nuclear (DAPI-blue) and TUNEL (Tetramethylrhodamine -red) of the SCJ sections from a mouse treated with the anti-CD8 antibody demonstrating significantly reduced TUNEL + nuclei in both the squamous and glandular compartments. $(\mathrm{x} 200$, white bar $=50 \mu \mathrm{m}) \mathrm{SQ}=$ squamous forestomach. $\mathbf{B}^{\prime}$ inset. Representative higher-power imaging demonstrating little TUNEL staining of the columnar metaplasia at the SCJ. B" inset. similar higher-power imaging for nuclei (DAPI-blue) and TUNEL (Tetramethylrhodamine-red) revealing little TUNEL labeling of the nuclei of anti-CD8 antibody treated $K 14-C d x 2: \because L 2-I L-1 \beta$ mice $n=3 K 14-C d x 2: \because L 2-I L-1 \beta$ mice for each treatment. 


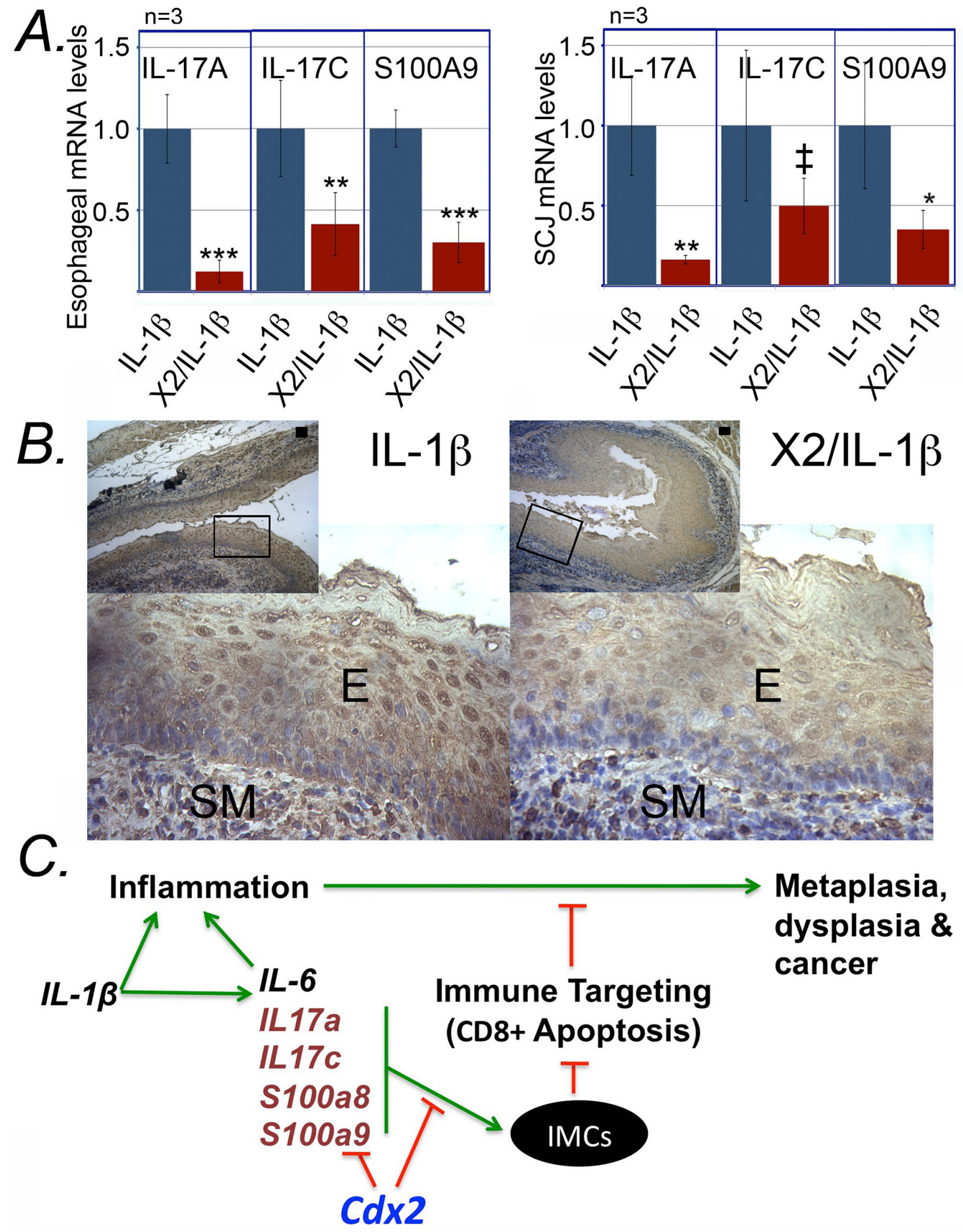

Figure 14: K14-Cdx2::L2-IL-1 $\beta$ transgenic mice have reduced expression of key regulators of immature myeloid cell inducers IL-17 and S100A8/a9. A. Relative IL-17A, IL-17C and S100A9 expression from esophageal and SCJ metaplasia tissues of $L 2-$ $I L-1 \beta$ and $K 14-C d x 2:: L 2-I L-1 \beta$ mice. $n=3$ mice in each group. Error bars display standard deviations; $p$ values based on one-sided student $T$-testing comparing gene expression in $L 2-I L-1 \beta$ and $K 14-C d x 2: \because L 2-I L-1 \beta$ mice; $\$ p=0.164 ; * p=0.049 ; * * p=0.036 ; * * * p \leq 0.018 ; n=3$ animals for each genotype, with each sample assayed in triplicate. B. Immunostaining for S100A9 in esophagi of $L 2-I L-1 \beta$ and $K 14-C d x 2:: L 2-$ $I L-1 \beta$ mice. E; squamous epithelium; SM: submucosa. $n=3$ mice in each group. C. Model for the onset of metaplasia in $L 2-I L-1 \beta$ mice, and its inhibition in $K 14-C d x 2:: L 2-I L-1 \beta$ mice. IMC: immature myeloid cells; Green arrows-enhancing activity, red lines-inhibitory function. 
our previously described $K 14-C d x 2$ mice with the $L 2$ $I L-1 \beta$ transgenic mice might yield a more advanced, aggressive intestinal metaplasia. However, the opposite result was obtained. In our exploration of the mechanism for this protection, we eliminated trivial possibilities, such as $\mathrm{Cdx} 2$ expression reducing esophageal IL- $1 \beta$ levels and systemic inflammation, or that $\mathrm{Cdx} 2$ expression reduced cell proliferation, thereby limiting metaplasia formation. In contrast, we clearly demonstrate a very novel mechanism, that $\mathrm{Cdx} 2$ expression is associated with an increase in $\mathrm{CD}^{+}$cell-dependent apoptosis in the developing metaplasia. We demonstrate a very significant reduction in a subpopulation of immature myeloid cells with immune suppressor properties, known by the cell surface marking $\mathrm{CD} 45^{+} \mathrm{CD} 11 \mathrm{~b}^{+} \mathrm{Gr}-1^{+}$. Based on the literature regarding these immature myeloid cells $[12,18]$, their loss or disruption in vivo typically leads to enhanced immunemediated disruption of tumor growth, often via the actions of cytotoxic T-cells [38], consistent with our findings. We therefore speculate that with the loss of the immune-

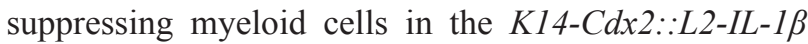
mice, there is increased immune mediated surveillance and targeting of the abnormal metaplastic cells, leading to the increased apoptosis we observe in the metaplastic nodules at the SCJ. Evidence for the CD11b $+\mathrm{Gr}-1+$ cells fulfilling this component of the model (Figure 7) is at present correlative but is fully consistent with the published literature on immature immune-suppressing myeloid cells. Formal testing of this mechanism is will be pursued in future experiments, including crossing the $L 2-I L-1 \beta$ mice with IL-17 and S100A9 knock-out and S100A9 over-expressing mice.

An additional important question we do not fully answer here is the mechanism by which esophageal $\mathrm{Cdx} 2$ expression inhibits the development and recruitment of these immature myeloid cells. We clearly demonstrate that $\mathrm{Cdx} 2$ expression reduces levels of proinflammatory S100A8/A9 proteins and also IL-17 in the esophagus, but transgenic IL-1 $\beta$ is entirely unaffected. This is an important distinction, as S100A8/A9 and IL-17 are known from multiple studies to be critical for the induction of immature myeloid cells in cancer $[12,18]$. Moreover, the S100A8/a9 and IL-17c proteins are expressed by squamous keratinocytes, esophageal epithelium, and Barrett's esophagus epithelium [23-27], and therefore may be directly affected by esophageal $\mathrm{Cdx} 2$. Together these findings suggest a $\mathrm{Cdx} 2$ expression in the esophagus reduces the production of the proinflammatory S100A8/a9 proteins and IL-17c (Figure 14).

However, elements of this mechanism remain unknown. Most critically is how the $\mathrm{Cdx} 2$ transgene yields this response, and this is a much harder question to address. We have explored $C d x 2$ 's role in intestinal biology [39-42] and observed that generally the transcription factor $\mathrm{Cdx} 2$ behaves as a transcriptional activator, not a repressor $[10,43]$. We performed an in silico analysis of all three genes to determine if $\mathrm{Cdx} 2$ is known to bind their promoter regions using the ENCODE and TRANSFAC databases $[44,45]$ but found no evidence for an interaction with these genes by $\mathrm{Cdx} 2$. Moreover, we explored published genome-wide analyses of $\mathrm{Cdx} 2$ binding sites in intestinal epithelial cells and found no reports that Cdx2 protein bound and regulated IL-17, S100A8/A9 genes $[46,47]$.

It is interesting to note that there are several published reports exploring interactions between proinflammatory cytokines, $\mathrm{NF}-\mathrm{\kappa B}$, and $\mathrm{Cdx} 2$. In gastric and cholangiocarcinoma cell lines, proinflammatory cytokines including IL-1 $\beta$, IL- 6 , and TNF- $\alpha$ have all been reported to induce $\mathrm{Cdx} 2$ gene expression [48-50]. Several studies have even suggested this may be mediated by NF$\kappa \mathrm{B}$ binding to the $\mathrm{Cdx} 2$ promoter $[51,52]$. In contrast, other studies have suggested Cdx2 may inhibit the NF- $\mathrm{kB}$ signaling pathway, possibly by binding the p65 subunit and inhibiting DNA binding of the NF-kB complex [53, 54]. We speculate that this latter mechanism may be how Cdx2 limits IL-17 and S100A8/9 expression. Until we clarify this mechanism, we cannot know whether $\mathrm{Cdx} 2$ plays a "protective" role, limiting disease progression to dysplasia and EAC by limiting the production of the immature myeloid cells. Therefore, this will remain an important focus for our future research efforts.

In many human cancers, immature myeloid cells have been under intense investigation due to their ability to promote tumor immune evasion and enhance tumorigenesis [12]. They are under investigation not only for the insights they yield into the pathogenesis of cancer, but for the potential therapeutic applications, including enhancement of anticancer immunotherapies [55]. Therefore, our work here, establishing their importance for disease onset in a mouse model for $\mathrm{BE}$ and $\mathrm{EAC}$, is extremely significant not only for these new insights into BE pathogenesis our work provides, but also for potentially novel avenues of research and therapeutics which should now be now explored for patients with advanced BE and EAC.

\section{MATERIALS AND METHODS}

\section{Animal studies}

All studies with the mouse models were fully approved by the Institutional Animal Care and Use Committee (IACUC) at the University of Pennsylvania (IACUC\#525400), and the animal care and use program conforms to all required standards. Mice were maintained in a specific pathogen-free facility with standard bedding and 12-hour light-dark cycles. The generation and genotyping of K14-Cdx2 [6] and L2-IL-1 $\beta$ [7] transgenic mice have been previously described. $K 14-C d x 2$ transgenic mice were crossed with $L 2-I L-1 \beta$ and yielded four genotypes analyzed for this study: K14-Cdx2::L2-IL-1 $\beta$ double transgenic, $L 2-I L-$ $1 \beta$ and $K 14-C d x 2$ single transgenic mice and corresponding 
wild type control as well. Mice were placed on drinking water containing deoxycholic acid (0.2\% DCA, pH7.0) at age of 8 weeks. After 12-months of treatment, mice were sacrificed for analysis. The nodules were measured and excised for routine pathological examination. The following nodule indicators were evaluated in each mouse by iVision software: the number of mice with nodules as well as the numbers of and the calculated volumes of the nodules per mouse.

\section{Morphometric analysis}

The squamocolumnar junction in HE-stained sections was evaluated for epithelial nodular hyperplasia, percentage of fields with mononuclear inflammatory infiltrates, neutrophilic inflammatory infiltrates, mucosal metaplasia, and mucosal lymphoid follicles. The extent of the histologic changes was assessed by determining the percentage of microscopic fields with positive criteria for lesions. All microscopic fields of each SCJ section were evaluated.

\section{Quantitative real-time PCR analysis}

Samples were stored in tissue storage reagent (RNAlater; Ambion, Austin, TX). Total RNA was isolated using RNeasy Mini kit (Qiagen, Valencia, CA). cDNA was prepared from total RNA using the SuperScript ${ }^{\circledR}$ VILO $^{\text {TM }}$ cDNA Synthesis Kit (Invitrogen, Carlsbad, CA). Primers were designed using Primer Express software (Applied Biosystems). Quantitative RT-PCR was performed on an ABI 7000 sequence detection system (Applied Biosystems, Foster City, CA), with SYBR green or Taqman as the fluorescent dye using standard PCR conditions. A dissociation curve was run with each PCR as a control. A ribosomal phosphoprotein, 36B4, was used as the normalization control.

The primer sequences used are as shown below: IL$1 \beta$ forward 5'-CAAGCAACGACAAAATACCTGTG-3'; reverse 5'-AGACAAACCGTTTTTCCATCTTCT-3';

IL-17A forward 5'-ATCCCTCAAAGCTCAGCGT GTC; reverse 5'-GGGTCTTCATTGCGGTGGAGAG-3'; IL-17C forward 5'-CCATGGAGATATCGCATCGA-3'; reverse 5'-GCATCCACGACACAAGCATT-3'; S100A9 forward 5'- CACAGTTGGCAACCTTTA TGA A -3'; reverse 5'- GGTCCTCCATGATGTCATTTATG -3'.

All the sequences of other primers used for real time PCR were described previously [6]. $p$ values were determined by analysis of variance and Tukey rank mean test. $\triangle \mathrm{Ct}$ values were calculated after duplicate PCRs for each sample as described, and statistical analysis was performed. $\Delta \Delta \mathrm{Ct}$ values were then calculated and used to determine fold-change in expression.

\section{Immunohistochemical analysis}

All specimens were isolated, rinsed in ice-cold PBS, fixed, and analyzed histologically by staining sections with hematoxylin and eosin (H\&E) or immunohistochemically using standard methods as described [6]. Five-mm paraffin- embedded sections were pretreated with xylene and then placed in a microwave oven in $10 \mathrm{mmol} / \mathrm{L}$ citric acid buffer. Endogenous peroxidases were quenched using hydrogen peroxide before sections were incubated in avidin D blocking reagent and biotin blocking reagent. Primary antibodies used include rabbit monoclonal $\mathrm{Cdx} 2$ (1:500, Abcam), Caspase 3 (1:500, Cell Signaling), Rabbit polyclonal Muc2 (1:100, Santa Cruz), mouse monoclonal anti-CD45 (1:250, cell signaling), rat anti-Gr-1/ NIMP-R14 (1:100, Abcam), mouse monoclonal MAC387 (1:1,000, Abcam), dendritic cell marker mouse monoclonal AP-MAB0801 (Abcam), rat anti-Ly-6G (1:1,000, BioXcell), Rabbit anti-Myeloperoxidase (1:500, Abcam), Rabbit anti- S100A9 (1:100, Novusbio). Sections were incubated with primary and biotinylated secondary antibodies and an avidin-horseradish peroxidase conjugate (Vectastain Elite ABC kit; Vector Laboratories, Burlingame, CA) following the manufacturer's protocol. The signal was developed using the 3,3-diaminobenzidine substrate kit (Vector Laboratories). Sections were counterstained with hematoxylin.

Alcian blue staining, slides were deparaffinized. After application of 3\% aqueous acetic acid to the slides, $1 \%$ Alcian blue in 3\% acetic acid, $\mathrm{pH} 2.5$, was applied. Sections were washed and counterstained with $0.1 \%$ nuclear fast red, dehydrated, and mounted. For immunofluorescence detection, the tissue sections were incubated with primary antibody overnight at $4{ }^{\circ} \mathrm{C}$ and secondary antibodies at $37^{\circ} \mathrm{C}$ for 30 minutes. After incubation, slides were washed with PBS three times, counterstained with DAPI, and then photographed with a Nikon E600 fluorescent microscope and confocal microscope.

\section{EdU cell proliferation assay}

The transgenic and wild-type littermates were injected intraperitoneally with EdU (Life Technologies) 1 hour prior to sacrifice, esophagus and squamo-columnar junction area were harvested and embedded in paraffin. $5 \mu \mathrm{m}$ thick sections were subjected to the Click-iT and subjected to the Click-iT EdU proliferation Assay (Life Technologies). EdU that had been incorporated into newly synthesized DNA was detected by Alexa Fluor 594 azide (red) and cell nuclei were stained with DAPI (blue) counterstain. All Images were captured at $10 \times$ and $20 \times$ magnification. Three random $10 \times$ fields were taken from each group of litter matched transgenic and wild type mice. The EdU positive proliferating cells were quantified and normalized to the total cell number in each field. The graph is generated from the average ratio (EdU/DAPI) of three $10 \times$ fields in each group.

\section{ELISA}

The levels of mouse IL-6 in sera of the transgenic mice were determined using an ELISA kit (BD Company, San Diego, CA). Absorbance was measured at $450 \mathrm{~nm}$ by a Tecan plate reader, and the samples were analyzed by Magellan 7.1 SP software. 


\section{TUNEL assay}

Apoptosis in sections was performed using In situ cell death detection kit with TMR Red according to the manufacturer instructions (Roche, West Sussex, UK) (Roche \#12 156792910 ) and stored at $4^{\circ} \mathrm{C}$ until analysis.

\section{RNA microarray analysis}

Microarray analyses were performed on triplicate RNA samples of SCJ metaplasia nodules from mice to identify differentially expressed genes comparing $L 2-I L$ $1 \beta$ forestomach and $K 14-C d x 2: \because L 2-I L-1 \beta$ forestomach. The total nodules from mouse SCJ were isolated and snap-frozen and stored at $-80^{\circ} \mathrm{C}$ for RNA preparation. cDNA was transcribed using $5 \mu \mathrm{g}$ total RNA (Affymetrix) and run on Affymetrix Mouse 1.0ST Affymetrix Arrays. The statistical test significance analysis of Microarrays was applied using a two-class unpaired analysis and differentially expressed genes were identified using a fold change cutoff of $\geq 1.5$ (up or down). Gene expression differences were considered statistically significant if the $p$-value was less than 0.01. A global test was done as to whether the expression profiles differed between the classes by permuting the labels of which arrays corresponded to which classes. The false discovery rate was estimated to be less than $0.13 \%$. Cluster analysis was performed with Cluster and Treeview software. Microarray files were submitted to the GEO repository; file GSE60320.

\section{Flow cytometry analysis}

Single-cell suspensions of fresh esophagi, SCJ metaplasia nodules, or spleen) were prepared. Spleens were crushed and passed through a $70-\mu \mathrm{m}$ cell strainer, treated with ACK Lysis Buffer (Invitrogen) and washed twice with RPMI $10 \%$ FCS. Esophagi and forestomachs were minced into $1-2 \mathrm{~mm}$ pieces, incubated in $1 \mathrm{mg} / \mathrm{mL}$ collagenase (Sigma-Aldrich) in RPMI for 45 minutes at $37^{\circ} \mathrm{C}$, and then were passed through a $70-\mu \mathrm{m}$ cell strainer and washed once RPMI $/ 10 \%$ FCS. Cells were stained in PBS $/ 0.5 \%$ FCS with the following antibodies: CD45 (Biolegend clone 30-F11), CD11c (clone HL3), antimouse CD45R (B220) FITC, CD3e (clone 145-2C11), CD49b (clone DX5), CD19 (clone 1D3) from eBioscience and Pacific Blue Ly-6G/Ly-6C (Gr-1) (clone RBG-8C5) from Biolegend, Anti-Mouse CD11b (clone M1/70) PE from eBiosciences, anti-Myeloperoxidase antibody [2D4] FITC from Abcam, F4/80 (clone C1:A3-1) from AbD Serotec. Flow cytometry was done using a BD FACSCanto or LSRII (BD Biosciences Immunocytometry Systems), and data were analyzed with BD FACSDiva software. Gates were set using negative controls and positive populations were corrected by subtraction of background and nonspecific binding of the antibody.
For CD8 ${ }^{+} \mathrm{T}$-cell ablation studies, $K 14-C d x 2: \because L 2-I L 1 \beta$ mice were injected on days one, three and five with 200 $\mu \mathrm{g}$ of anti-mouse CD8a (clone 53-6.72) or isotype control (clone 2A) antibodies from BioXcell. On the sixth day, blood, spleens and esophagi were collected for flow cytometry confirmation of decreased $\mathrm{CD}^{+}$cells. SCJ metaplasia sections were fixed for histology and TUNEL assays.

\section{In vitro $\mathbf{T}$ cells suppression assay}

To evaluate the ability of CD11 $\mathrm{b}^{+} \mathrm{Gr}-1+$ myeloidderived suppressor cells (MDSC) isolated from the spleen from $L 2-I L-1 \beta$ transgenic mice to suppress antigen specific $\mathrm{T}$ cell proliferation, we performed a T-cell proliferation assay. A single cell suspension of splenocytes isolated from wild-type mice was made by homogenizing spleen with a $1 \mathrm{ml}$ syringe through a $70 \mu \mathrm{M}$ filter into a $50 \mathrm{ml}$ conical tube. Red blood cells were lysed using lysis solution and quenched with HBSS. Red blood cell depleted murine splenocytes were resuspended at $1 \times 10^{6} / \mathrm{ml}$ and labeled with $5 \mu \mathrm{M}$ green fluorochrome carboxyfluorescein succinimidyl ester (CFSE). Cells were activated with anti-CD3/CD28 coated beads (Gibco, Life technologies) and seeded in triplicate and cultured in RPMI-1640 supplemented with $10 \%$ fetal bovine serum. Splenocytes were cultured either alone or in the presence

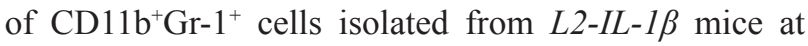
different ratios $0: 1,1: 1,1: 2,1: 4,1: 8,1: 16$. After $72 \mathrm{~h}$, cells were collected and stained with 7AAD, anti-CD45, CD3, CD4, Gr-1 and CD11b mAbs cocktail. Proliferation was determined by CFSE dilution and flow cytometric analysis on a FACSLSRII cytometer (BD Biosciences) with initial gating on the $\mathrm{CD}^{+} / \mathrm{CD}^{+}$populations.

\section{Statistical analysis}

GraphPad Prism version 3.04 was used for all statistical analyses (GraphPad, San Diego, CA, USA). For power analysis GraphPad Statmate or G*power3 was used. All data are represented as mean and standard deviation unless otherwise stated with $p$-value cutoff of $\leq 0.05$ unless otherwise indicated. Replicate numbers and specific statistical tests employed are indicated in the figure legends.

All authors had access to the study data and had reviewed and approved the final manuscript.

\section{ACKNOWLEDGMENTS AND FUNDING}

We would like to thank the University of Pennsylvania Morphology and Pathology Imaging Core facility for their technical expertise and assistance. This work is supported as part of the NCI BETRNet program (CA163004 TCW, AKR and JPL), and an NIH K26 career development award to JPL (OD 012097). This work was also supported by an NCI Program Project PO1 CA098101 (AKR) and the Molecular Biology and Imaging, Cell Culture, Molecular Biology 
and Transgenic and Chimeric Mouse Core Facilities of the Center for Molecular Studies in Digestive and Liver Disease at the University of Pennsylvania (P30-DK050306 and PO1 CA098101)(AKR).

Funding agencies had no role in the study design, or the collection, analysis, and interpretation of the data.

\section{CONFLICTS OF INTEREST}

There are no conflicts of interest to disclose for all authors

\section{Author contributions}

Jianping Kong - study concept and design; acquisition of data; technical or material support; interpretation of data; drafting of the manuscript;

Hong Sai- acquisition of data; technical or material support;

Mary Ann Crissey - acquisition of data; analysis and interpretation of data;

Nirag Jhala - acquisition of data; technical or material support; interpretation of data;

Gary W. Falk - study concept and design; interpretation of data;

Gregory G. Ginsberg - study concept and design; interpretation of data;

Julian A. Abrams - study concept and design; interpretation of data;

Hiroshi Nakagawa - study concept and design; interpretation of data, technical or material support;

Kenneth Wang - study concept and design; interpretation of data;

Anil K. Rustgi - study concept and design; acquisition of data; technical or material support; interpretation of data;

Timothy C. Wang - study concept and design; technical or material support; interpretation of data;

John P Lynch - study concept and design; study supervision; technical or material support; analysis and interpretation of data; acquisition of data; drafting of the manuscript.

\section{Editorial note}

This paper has been accepted based in part on peerreview conducted by another journal and the authors' response and revisions as well as expedited peer-review in Oncotarget.

\section{REFERENCES}

1. Shaheen NJ. What is behind the remarkable increase in esophageal adenocarcinoma? Am J Gastroenterol. 2014; 109:345-347.
2. Picardo SL, Maher SG, O'Sullivan JN, Reynolds JV. Barrett's to oesophageal cancer sequence: a model of inflammatory-driven upper gastrointestinal cancer. Dig Surg. 2012; 29:251-260.

3. Stairs DB, Kong J, Lynch JP. Cdx genes, inflammation, and the pathogenesis of intestinal metaplasia. Progress in Molecular Biology and Translational Science. 2010; 96:231-270.

4. Spechler SJ, Fitzgerald RC, Prasad GA, Wang KK. History, molecular mechanisms, and endoscopic treatment of Barrett's esophagus. Gastroenterology. 2010; 138:854-869.

5. Sharma P. Clinical practice. Barrett's esophagus. N Engl J Med. 2009; 361:2548-2556.

6. Kong J, Crissey MA, Funakoshi S, Kreindler JL, Lynch JP. Ectopic Cdx2 Expression in Murine Esophagus Models an Intermediate Stage in the Emergence of Barrett's Esophagus. PLoS ONE. 2011; 6:e18280.

7. Quante M, Bhagat G, Abrams JA, MaracheF, Good P, Lee MD, Lee Y, Friedman R, Asfaha S, Dubeykovskaya Z, Mahmood U, Figueiredo JL, Kitajewski J, Shawber C, Lightdale CJ, Rustgi AK, et al. Bile Acid and inflammation activate gastric cardia stem cells in a mouse model of barrettlike metaplasia. Cancer Cell. 2012; 21:36-51.

8. Nakagawa H, Wang TC, Zukerberg L, Odze R, Togawa K, May GH, Wilson J, Rustgi AK. The targeting of the cyclin D1 oncogene by an Epstein-Barr virus promoter in transgenic mice causes dysplasia in the tongue, esophagus and forestomach. Oncogene. 1997; 14:1185-1190.

9. Nakagawa H, Whelan K, Lynch JP. Mechanisms of Barrett's oesophagus: Intestinal differentiation, stem cells, and tissue models. Best Pract Res Clin Gastroenterol. 2015; 29:3-16.

10. Stairs DB, Kong J, Lynch J.P. Cdx genes, inflammation, and the pathogenesis of intestinal metaplasias. Molecular Biology of Digestive Organs: Elsevier). Kaestner K. 2010; pp. 231-270.

11. Solito S, Marigo I, Pinton L, Damuzzo V, Mandruzzato S, Bronte V. Myeloid-derived suppressor cell heterogeneity in human cancers. Ann N Y Acad Sci. 2014; 1319:47-65.

12. Talmadge JE, Gabrilovich DI. History of myeloid-derived suppressor cells. Nat Rev Cancer. 2013; 13:739-752.

13. Stairs DB, Bayne LJ, Rhoades B, Vega ME, Waldron TJ, Kalabis J, Klein-Szanto A, Lee JS, Katz JP, Diehl JA, Reynolds AB, Vonderheide RH, Rustgi AK. Deletion of p120-catenin results in a tumor microenvironment with inflammation and cancer that establishes it as a tumor suppressor gene. Cancer Cell. 2011; 19:470-483.

14. Guo R, Funakoshi S, Lee HH, Kong J, Lynch JP. The intestine-specific transcription factor $\mathrm{Cdx} 2$ inhibits betacatenin/TCF transcriptional activity by disrupting the beta-catenin/ TCF protein complex. Carcinogenesis. 2010; 31:159-166.

15. Dang LH, Chen F, Ying C, Chun SY, Knock SA, Appelman HD, Dang DT. CDX2 has tumorigenic potential in the human colon cancer cell lines LOVO and SW48. Oncogene. 2006; 25:2264-2272. 
16. Hinkel I, Duluc I, Martin E, Guenot D, Freund JN, Gross I. $\mathrm{Cdx} 2$ controls expression of the protocadherin Mucdhl, an inhibitor of growth and beta-catenin activity in colon cancer cells. Gastroenterology. 2012; 142:875-885.

17. Huang da W, Sherman BT, Lempicki RA. Systematic and integrative analysis of large gene lists using DAVID bioinformatics resources. Nat Protoc. 2009; 4:44-57.

18. Gabrilovich DI, Ostrand-Rosenberg S, Bronte V. Coordinated regulation of myeloid cells by tumours. Nat Rev Immunol. 2012; 12:253-268.

19. Singh I. Textbook of Human Histology: (with Colour Atlas \& Practical Guide). 2011; London, UK: Jaypee Brothers Medical Publishers.

20. Nagaraj S, Gabrilovich DI. Regulation of suppressive function of myeloid-derived suppressor cells by CD4+ T cells. Semin Cancer Biol. 2012; 22:282-288.

21. Sinha P, Okoro C, Foell D, Freeze HH, Ostrand-Rosenberg S, Srikrishna G. Proinflammatory S100 proteins regulate the accumulation of myeloid-derived suppressor cells. J Immunol. 2008; 181:4666-4675.

22. Yazawa T, Shibata M, Gonda K, Machida T, Suzuki S, Kenjo A, Nakamura I, Tsuchiya T, Koyama Y, Sakurai K, Shimura T, Tomita R, Ohto H, Gotoh M, Takenoshita S. Increased IL-17 production correlates with immunosuppression involving myeloid-derived suppressor cells and nutritional impairment in patients with various gastrointestinal cancers. Mol Clin Oncol. 2013; 1:675-679.

23. Sabo E, Meitner PA, Tavares R, Corless CL, Lauwers GY, Moss SF, Resnick MB. Expression analysis of Barrett's esophagus-associated high-grade dysplasia in laser capture microdissected archival tissue. Clin Cancer Res. 2008; 14:6440-6448.

24. Bax DA, Siersema PD, Haringsma J, Kuipers EJ, Vos AJ, Van Dekken H, Van Vliet AH, Kusters JG. High-grade dysplasia in Barrett's esophagus is associated with increased expression of calgranulin A and B. Scand J Gastroenterol. 2007; 42:902-910.

25. Bannister JR, Khan AL, Eccleston DW, Deol-Poonia RK, Hughes SF. Interleukin-17 Expression in the Barrett's Metaplasia-Dysplasia-Adenocarcinoma Sequence. ISRN Inflamm. 2012; 2012:578149.

26. Johnston A, Fritz Y, Dawes SM, Diaconu D, Al-Attar PM, Guzman AM, Chen CS, Fu W, Gudjonsson JE, McCormick TS, Ward NL. Keratinocyte overexpression of IL-17C promotes psoriasiform skin inflammation. J Immunol. 2013; 190:2252-2262.

27. Schonthaler HB, Guinea-Viniegra J, Wculek SK, Ruppen I, Ximenez-Embun P, Guio-Carrion A, Navarro R, Hogg N, Ashman K, Wagner EF. S100A8-S100A9 protein complex mediates psoriasis by regulating the expression of complement factor C3. Immunity. 2013; 39:1171-1181.

28. Hartman KG, Bortner JD Jr., Falk GW, Ginsberg GG, Jhala N, Yu J, Martin MG, Rustgi AK, Lynch JP. Modeling human gastrointestinal inflammatory diseases using microphysiological culture systems. Exp Biol Med (Maywood). 2014; 239:1108-1123.

29. Rieder F, Biancani P, Harnett K, Yerian L, Falk GW. Inflammatory mediators in gastroesophageal reflux disease: impact on esophageal motility, fibrosis, and carcinogenesis. Am J Physiol Gastrointest Liver Physiol. 2010; 298:G571-581.

30. Dvorakova K, Payne CM, Ramsey L, Holubec H, Sampliner R, Dominguez J, Dvorak B, Bernstein H, Bernstein C, Prasad A, Fass R, Cui H, Garewal H. Increased expression and secretion of interleukin- 6 in patients with Barrett's esophagus. Clin Cancer Res. 2004; 10:2020-2028.

31. Fitzgerald RC, Onwuegbusi BA, Bajaj-Elliott M, Saeed IT, Burnham WR, Farthing MJ. Diversity in the oesophageal phenotypic response to gastro-oesophageal reflux: immunological determinants. Gut. 2002; 50:451-459.

32. Kohata Y, Fujiwara Y, Machida H, Okazaki H, Yamagami H, Tanigawa T, Watanabe K, Watanabe T, Tominaga K, Wei M, Wanibuchi H, Arakawa T. Role of Th-2 cytokines in the development of Barrett's esophagus in rats. J Gastroenterol. 2011; 46:883-893.

33. Zhong YQ, Lin Y, Xu Z. Expression of IFN-gamma and IL-4 in the Esophageal Mucosa of Patients with Reflux Esophagitis and Barrett's Esophagus and Their Relationship with Endoscopic and Histologic Grading. Dig Dis Sci. 2011; 56:2865-2870.

34. Moons LM, Kusters JG, Bultman E, Kuipers EJ, van Dekken H, Tra WM, Kleinjan A, Kwekkeboom J, van Vliet AH, Siersema PD. Barrett's oesophagus is characterized by a predominantly humoral inflammatory response. J Pathol. 2005; 207:269-276.

35. Somja J, Demoulin S, Roncarati P, Herfs M, Bletard N, Delvenne P, Hubert P. Dendritic cells in Barrett's esophagus carcinogenesis: an inadequate microenvironment for antitumor immunity?. Am J Pathol. 2013; 182:2168-2179.

36. Eda A, Osawa H, Satoh K, Yanaka I, Kihira K, Ishino Y, Mutoh H, Sugano K. Aberrant expression of CDX2 in Barrett's epithelium and inflammatory esophageal mucosa. J Gastroenterol. 2003; 38:14-22.

37. Moons LM, Bax DA, Kuipers EJ, Van Dekken H, Haringsma J, Van Vliet AH, Siersema PD, Kusters JG. The homeodomain protein CDX2 is an early marker of Barrett's oesophagus. J Clin Pathol. 2004; 57:1063-1068.

38. Cheng P, Corzo CA, Luetteke N, Yu B, Nagaraj S, Bui MM, Ortiz M, Nacken W, Sorg C, Vogl T, Roth J, Gabrilovich DI. Inhibition of dendritic cell differentiation and accumulation of myeloid-derived suppressor cells in cancer is regulated by S100A9 protein. J Exp Med. 2008; 205:2235-2249.

39. Keller MS, Ezaki T, Guo RJ, Lynch JP. Cdx1 or Cdx2 Expression Activates E-Cadherin-mediated Cell-cell Adhesion and Compaction in Human Colo 205 cells. Am J Physiol Gastrointest Liver Physiol. 2004; 287:G104-114. 
40. Ezaki T, Guo RJ, Li H, Reynolds AB, Lynch JP. The homeodomain transcription factors $\mathrm{Cdx} 1$ and $\mathrm{Cdx} 2$ induce E-cadherin adhesion activity by reducing beta- and p120catenin tyrosine phosphorylation. Am J Physiol Gastrointest Liver Physiol. 2007; 293:G54-65.

41. Funakoshi S, Ezaki T, Kong J, Guo RJ, Lynch JP. Repression of the Desmocollin 2 gene in colorectal cancer cells is relieved by the homeodomain transcription factors $\mathrm{Cdx} 1$ and Cdx2. Molecular Cancer Research. 2008; 6:1478-1490.

42. Funakoshi S, Kong J, Crissey MA, Dang L, Dang D, Lynch JP. $\mathrm{Cdx} 2$ promotes E-cadherin function and cell-cell adhesion in colon cancer cells by enhancing E-cadherin trafficking to the cell membrane. Submitted. 2010; .

43. Guo RJ, Suh ER, Lynch JP. The Role of Cdx Proteins in Intestinal Development and Cancer. Cancer Biol Ther. 2004; 3:593-601.

44. Rosenbloom KR, Armstrong J, Barber GP, Casper J, Clawson H, Diekhans M, Dreszer TR, Fujita PA, Guruvadoo L, Haeussler M, Harte RA, Heitner S, Hickey G, Hinrichs AS, Hubley R, Karolchik D, et al. The UCSC Genome Browser database: update. Nucleic Acids Res. 2015; 43:D670-681.

45. Wingender E. The TRANSFAC project as an example of framework technology that supports the analysis of genomic regulation. Brief Bioinform. 2008; 9:326-332.

46. Boyd M, Hansen M, Jensen TG, Perearnau A, Olsen AK, Bram LL, Bak M, Tommerup N, Olsen J, Troelsen JT. Genome-wide analysis of CDX2 binding in intestinal epithelial cells (Caco-2). J Biol Chem. 2010; 285:25115-25125.

47. Verzi MP, Hatzis P, Sulahian R, Philips J, Schuijers J, Shin H, Freed E, Lynch JP, Dang DT, Brown M, Clevers H, Liu XS, Shivdasani RA. TCF4 and CDX2, major transcription factors for intestinal function, converge on the same cisregulatory regions. Proc Natl Acad Sci U S A. 2010; 107:15157-15162.
48. Ikeda H, Sasaki M, Ohira S, Ishikawa A, Sato Y, Harada K, Zen Y, Nakanuma Y. Tumor necrosis factor-alpha induces the aberrant expression of mucus core protein-2 in non-neoplastic biliary epithelial cells via the upregulation of CDX2 in chronic cholangitis. Hepatol Res. 2008; 38:1006-1017.

49. Li J, Wang GB, Sun RH, Tao KX. Significance of IL-1betainduced ectopic expression of CDX2 in the intestinal metaplasia of gastric epithelium. Zhonghua Wei Chang Wai Ke Za Zhi. 2010; 13:524-527.

50. Cobler L, Pera M, Garrido M, Iglesias M, de Bolos C. CDX2 can be regulated through the signalling pathways activated by IL-6 in gastric cells. Biochim Biophys Acta. 2014; 1839:785-792.

51. Debruyne PR, Witek M, Gong L, Birbe R, Chervoneva I, Jin T, Domon-Cell C, Palazzo JP, Freund JN, Li P, Pitari GM, Schulz S, Waldman SA. Bile acids induce ectopic expression of intestinal guanylyl cyclase $\mathrm{C}$ Through nuclear factor-kappaB and $\mathrm{Cdx} 2$ in human esophageal cells. Gastroenterology. 2006; 130:1191-1206.

52. Domon-Dell C, Wang Q, Kim S, Kedinger M, Evers BM, Freund JN. Stimulation of the intestinal Cdx2 homeobox gene by butyrate in colon cancer cells. Gut. 2002; 50:525-529.

53. Kim SP, Park JW, Lee SH, Lim JH, Jang BC, Jang IH, Freund JN, Suh SI, Mun KC, Song DK, Ha EM, Lee WJ, Kwon TK. Homeodomain protein CDX2 regulates COX-2 expression in colorectal cancer. Biochem Biophys Res Commun. 2004; 315:93-99.

54. Mutoh H, Hayakawa H, Sakamoto H, Sugano K. Homeobox protein CDX2 reduces Cox-2 transcription by inactivating the DNA-binding capacity of nuclear factor-kappaB. J Gastroenterol. 2007; 42:719-729.

55. Khaled YS, Ammori BJ, Elkord E. Myeloid-derived suppressor cells in cancer: recent progress and prospects. Immunol Cell Biol. 2013; 91:493-502. 